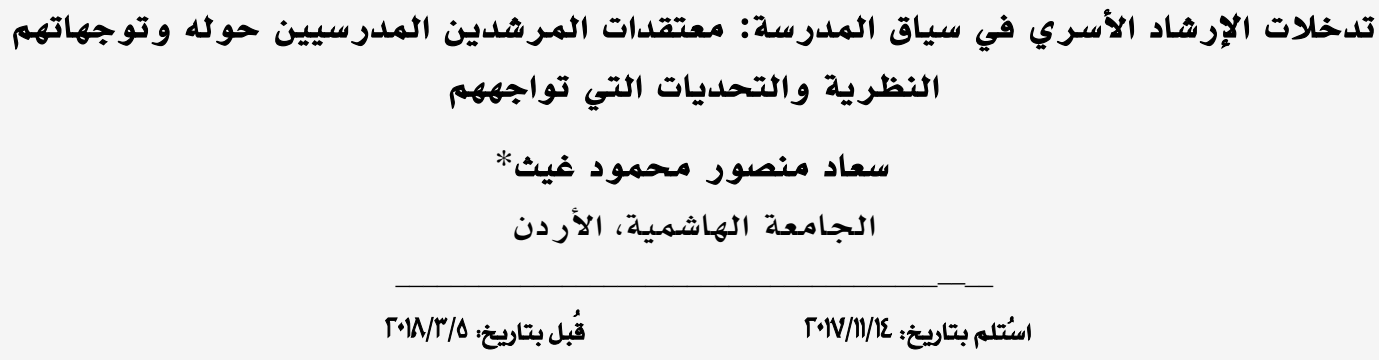

\title{
School Based Family Counseling Interventions in the School: School Counselors' Beliefs, Theoretical Orientation, and Challenges Facing Them
}

Suad M. Ghaith*

Hashemite University, Jordan

Abstract: This study aimed at identifying the level of implementing School Based Family Counseling (SBFC) Interventions among school counselors in their work, their theoretical orientation, beliefs, their degree of readiness to use it in their schools and factors that challenge the implementation of SBFC. To address the questions of the study, the researcher constructed a school based family counseling questionnaire which consisted of three parts. The sample of the study consisted of 91 male and female school counselors selected from Jordanian public schools in four governmental directorates. The results of the study revealed that $79.1 \%$ of the school counselors use SBFC interventions. They also showed that behavioral family counseling was the most widely used among the participants, whereas family systems theories were the least used. Moreover, the results indicated that school counselors had strong positive beliefs about implementing SBFC, but their degree of readiness to implement SBFC and the challenges of implementing SBFC interventions were moderate.

Keywords: School counselors, school based family counseling, family systems.

*drsghaith8@yahoo.com 
نهـوذجي" ، لتسـهـيل مثـل هـذه العمليـة مـن التتسـيق

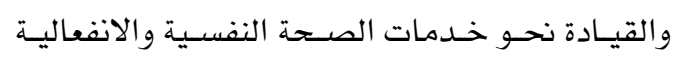

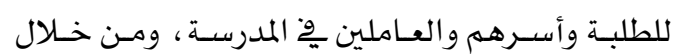
الانطـلاق للعهـل التعـاوني مـع المجتهــع المحلـي خـارج

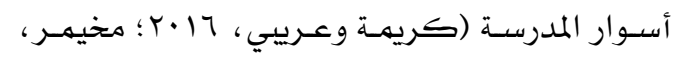
Henry, Bryan, \&. Zalaquett, 2017; ү.।

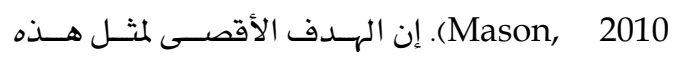

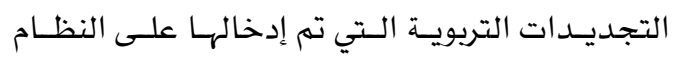
المدرسي هو تعزيز و تتمية فرص الطلبة مـن الأطفـال

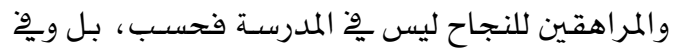

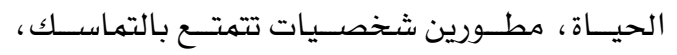

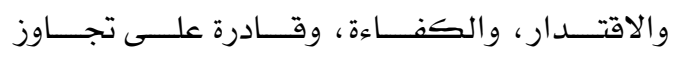

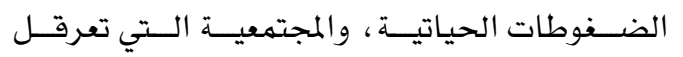
نجاحهم وتعلهه (Griffin \& Steen, 2010). لقـد ظهـرت نهـاذج نظريـة عـدة تشـرح وتقـترح صـور الشـراكة مـا بـــن المدرســة والأســر والمجتهـع؛؛ ومـن

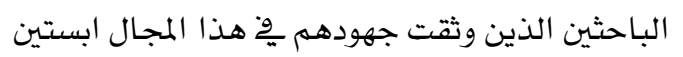

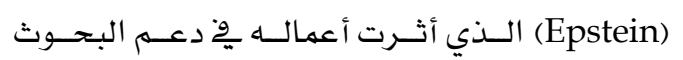

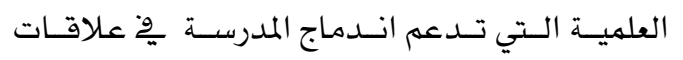
متبادلة مع الأسـر ومؤسسـات المجتمـع، من خلال ستة

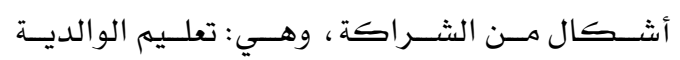

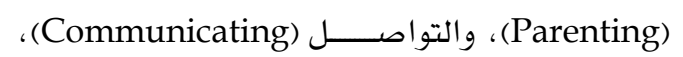

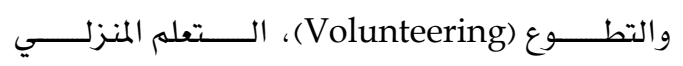

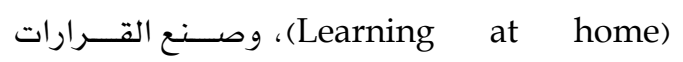

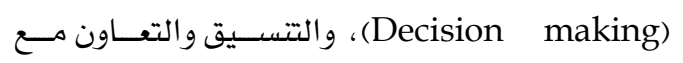
المجتهع (Collaborating with the community) .(Cook, Bryan \& Belford, 2016) وتوالـت جهـود البـاحثين مـن بعـده، منهــا مـا اهـتم بوصــف عمليــة الشــراكة بــين المدرســة والأســر ومؤسســات المجتهــع، مثـل الأنهــوذج الـذي قدمتــهـ برايـان وهنــري (Bryan \& Henery, 2012)

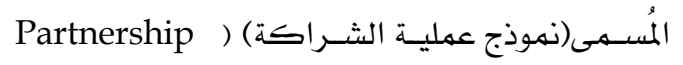
Process Model )، والمؤلف من ست مراحل: المرحلـة الأولى: الاسـتعد اد للشــراكة ، وذلــك مـن خـلال الـوعي بالاتجـاهـات والقـيم والمعتقــــات الـتي
لقد ضـمت حركـة الإصـلاح التربوي Education)

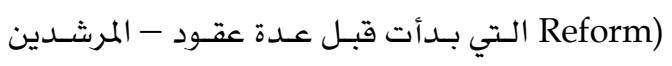
التربـويين، والعـاملين يوْ الإرشــاد المدرسـي مطالبـة

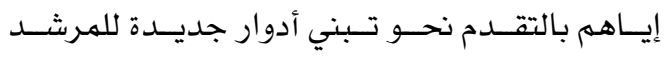
النفسـي والتربـوي الـذي أصـبح هـو وطلبتـهـ، والهيئة التدريسية ، والإداريـة يخ المدرسـة يواجهـون تحسديات

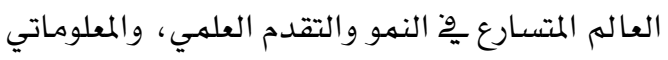
والتقني (Stone \& Dahir, 2015) ، إنّ هـذه الأدوار

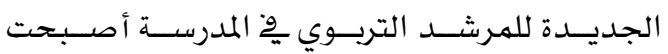
تتضهن أن يكون المرشد قائداً (Leader) ، ومنسقاً

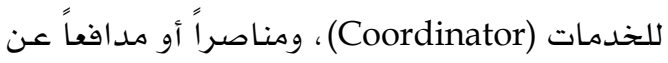

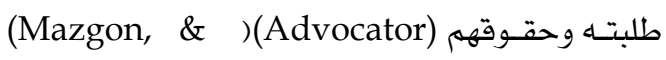
Mrvar, 2017) والاعتياديـة للمرشـد المدرسـي والتربـوي التي ظلّ ولا يزال يهارسها خلال العقود الماضية (Carter, 2016).

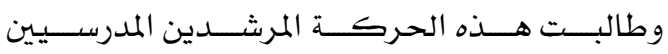

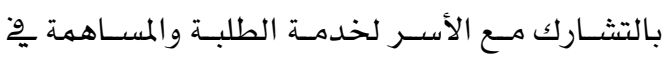
تحســن فـرص نهـوهـم الشخصـي، واسـتجابة لهـذه

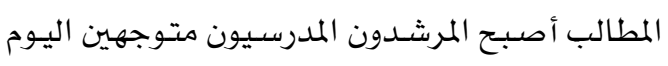

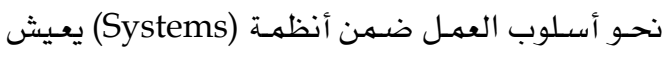

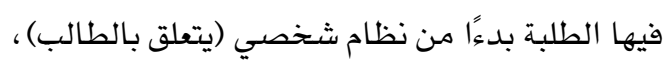

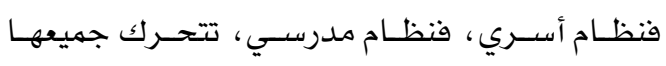

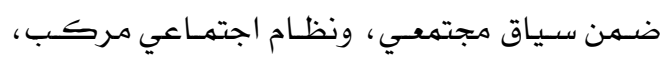

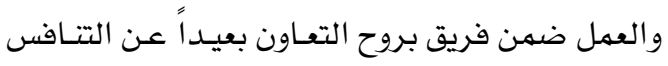

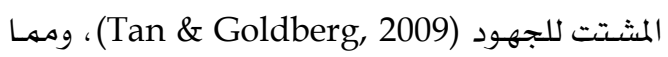
يببرد هــا الأسـلوب وِ خدمهـة الطلبـة أن العديـد مـن

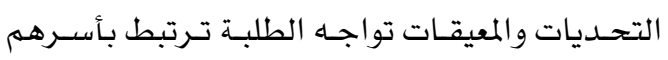

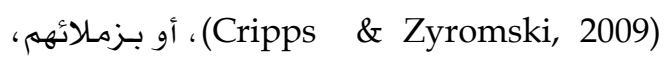

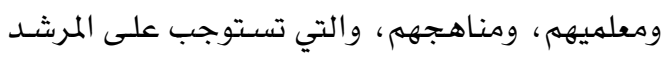

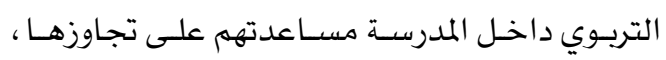

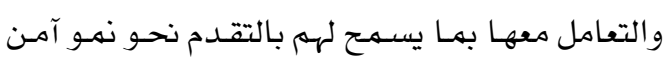
(Farrell \& Collier, 2010; Ludwig, وصحي

إنّ تبني توجها يقوم على التسـيق والرؤيـة التكامليـة والشـاملة يهكـن أن ييسـر مواجهـة هـــه التحـديات

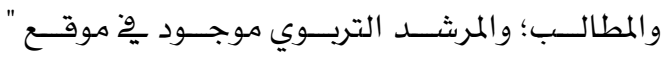




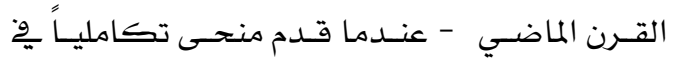

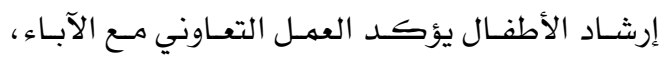
والمعلمين، والأخصائيـين النفسيـين من خلال عيـادات

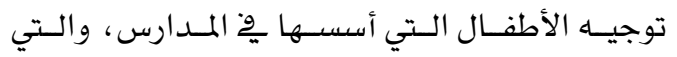
كانت تهدف إلى توظيف المعرفة النفسية ِِّ النظـام التعليمي. يعتبر هذا الأسلوب متسقاً مع فلسـفة آدلـر الـتي تتضـمن العهـل مـع الأنظهـة الـتي يعـيش فيهـا

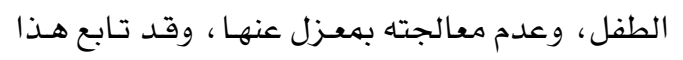

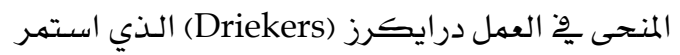

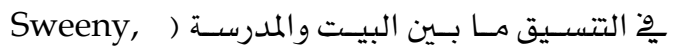
.(2009

لقد توالت بعد ذلك الجهود التي توضح قيهـة وفائـدة

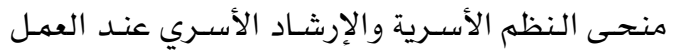

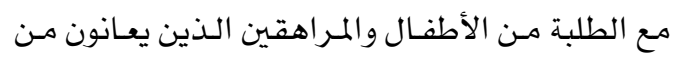

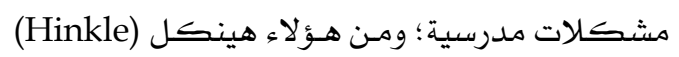
مؤلف كتاب الإرشاد الأسـري پِّ المدرسة عام ب199 199 "Family Counseling in the School" "

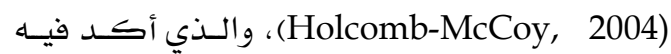
على أهمية وقدرة المرشد المدرسـي على تتفيـذ وتبني

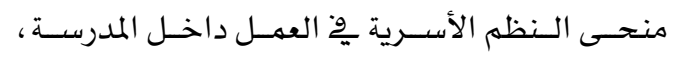

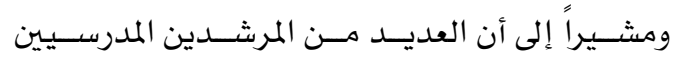

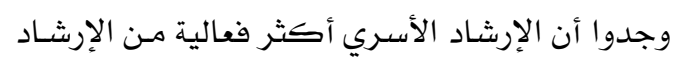
الفردي المطول للطلبة.

وتـلا ذلـك ظهـور مقالـة لـودي و ودي ( \&oody

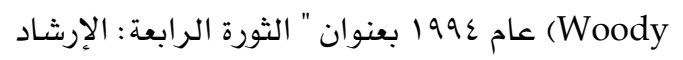

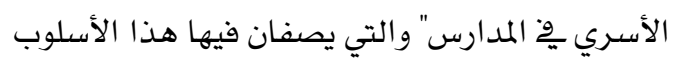
هِّ العهل الإرشـادي على أنها يهثل ثورةً وأن إدخال

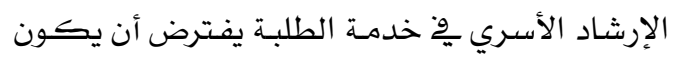

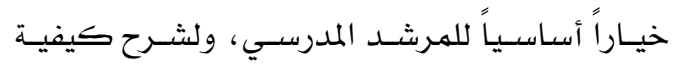

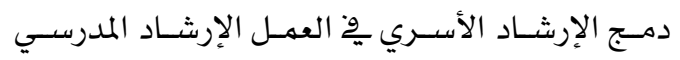

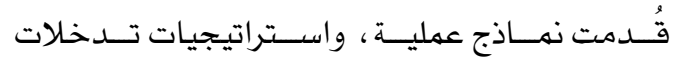

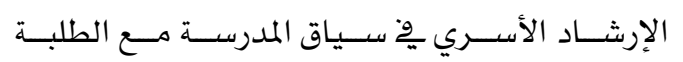

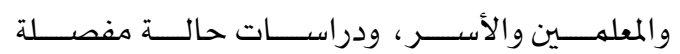
(Sheridan , Kratochwill, Burt \& Clarke, .2009)

واستمـر الاهتمـام بـدور المرشــ ِِّ التعـاون والتشــارك مع أسـر الطلبـة وحتى المجتهــع المحلـي لخدمـة الطلبـة
يحملها المرشـد نحو الطلبـة والأسـر والمؤسسـات التي

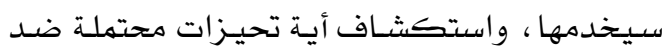
فكرة الشراكة.

المرحلة الثانية: تقييم الحاجات، ومصادر القوة التي تتوافر داخل المدرسة ، ويٌْ مؤسسـات الشراكة وبهـا يتسق مع متطلبات الشـراكة . المرحلـة الثالثة: تثــكيل فريـق قيـادة الثـراكة ، المؤلف من كافة المعنيين بعملية الشراكة من داخل وخـارج المدرســة ، مـن أجــل التخطـيط، والتتفيـذ ، والمتابعة والتقييم والمتابعة لخطة وبرنامج الشـراكة. المرحلـة الرابعـة : تطــوير رؤيسـة مشـتركة وخطــة ، والتأكيد على أهميـة تحقيق مشـاركة المعنيـين مـن خارج المدرسـة ، من أسر ومؤسسـات، وضهـان احترام التنوع الثقايِّ.

المرحلـة الخامســة : العهـل واتخــاذ الإجــراءات الـتي تضهن تتفيذ التدخلات التي تم تخطيطها. المرحلة السادسة: التركيز على التقيـيم، والاحتقـال بالإنجازات المحافظــة علـى المكتســبـات والانجــازات الــتي تم الوصول إليها.

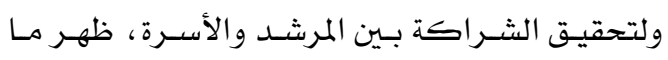

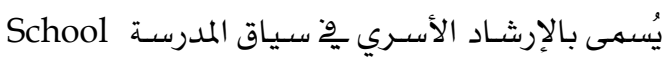

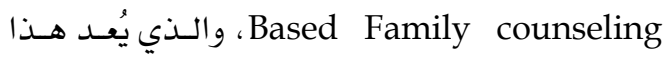

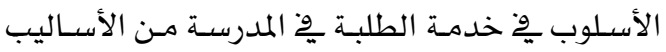
الـتي اسـتـدت علـى دعـوات العديـــ مـن المنظـرين،

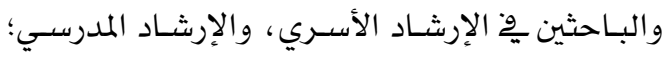

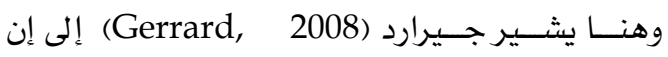

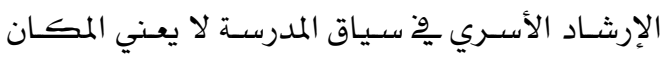

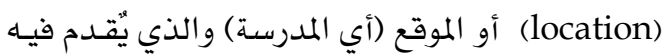
الإرشاد ، بقدر ما يتضهنه من تركيز وتأكيد على تطـوير النجـاح المدرسـي وتتهيتـه ودعمـه ، والتوافق والتـكيف داخـل المدرســة مـن خـلال العهـل التعـاوني

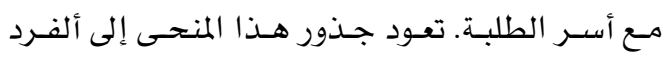

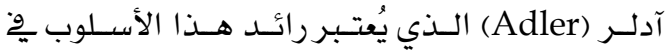

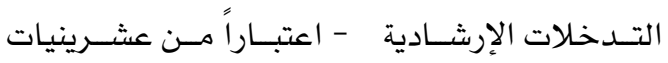




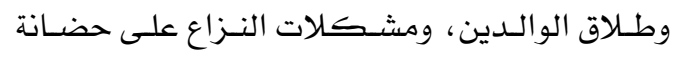

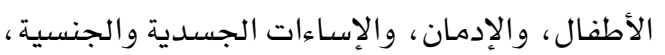

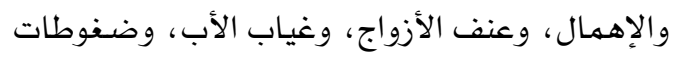

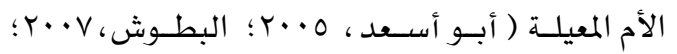

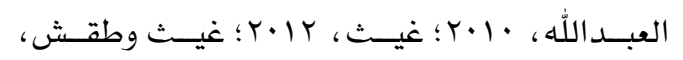
Sheridan, et al., 2009; Crespi \& ؛ .1. Hughes, 2004

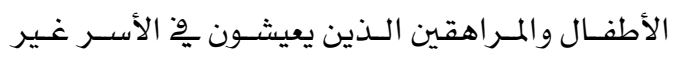
الوظيفيـة وغير الصـحية مـن العديـد مـن المشــكلات مثــلـل اضــطراب الســـلوك، والجنـــوح، والقلــق، ،

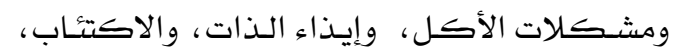

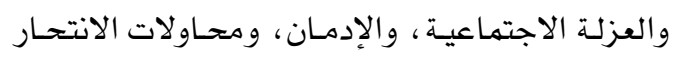

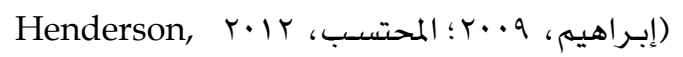
Sager \& Horne, 2003) تـــــاخل مــع توافـق الطلبــة المدرســي، ونجـــاحهم الأكاديمي والشخصي. وتشير دراسـات أخرى إلى مزايا تربية الأطفال ِِّ جـو

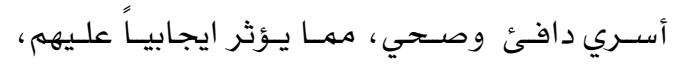

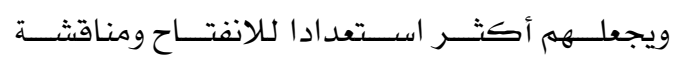
قضــاياهم الصــبة ، كـــلك فـإن الجــو الأســري الصحي يعمل على إيجـاد بيئـة أسـرية مناسـب للتعلم

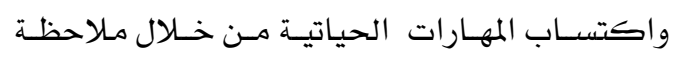
الوالدين (Laible, 2011; Diorio, 2016). إنّ هـــه

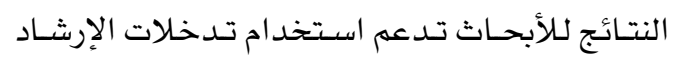
الأسري يِّ المدرسة. إنّ نسـبة المقـالات ِوِْ أدب الإرشـاد والعـلاج الأسـري

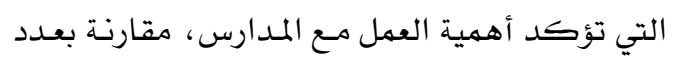

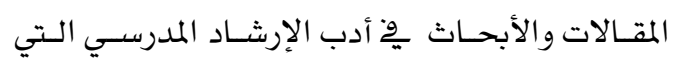

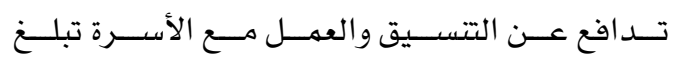
ع:ا(Carter \& Evans, 2008) ؛وهـي نتيجـة تثـير

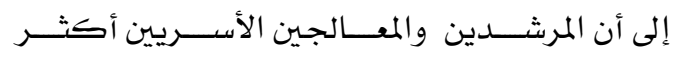

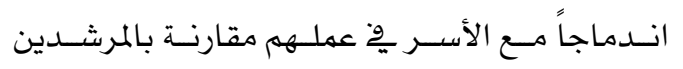

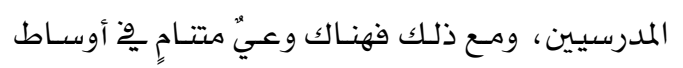

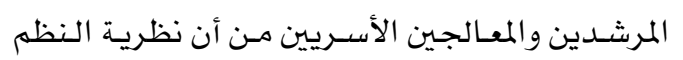

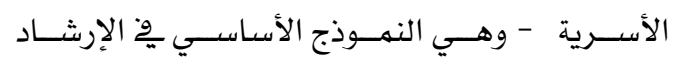

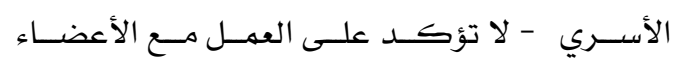

علـى النــــو الأفضـل، وتم التعبير عـن هـذا التوجـهـ

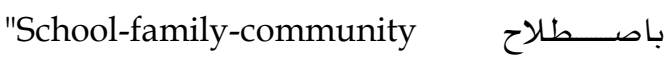
partnerships" والأسرة والمجتهع بقيادة المرشد المدرسي

Bryan \& Henry, 2008; Ludwing,2016; .(Mellin, Belknap, Brodie, \& Sholes, 2015) لقــ ظهـرت الحـاجـة للإرشــاد الأسـري نتيجــة عـدم

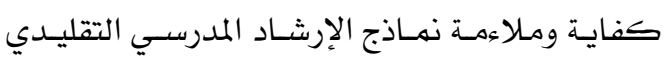
الـتي تعتمــد على النهـوذج الفـردي ( Individual موِْ مسـاعدة الطلبـة الـذين يخفقـون (Perspective

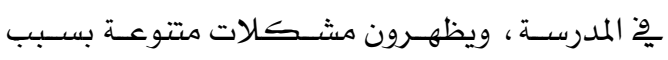

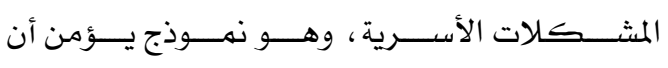

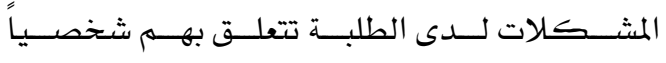

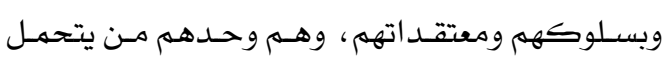

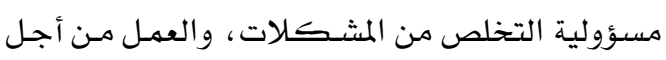
التفير، مِ حين أن مشككلاتهم التي تبدو عليهم ذات

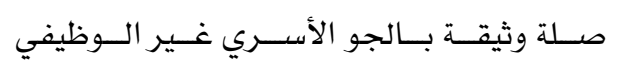
(dysfunctional) ، وانعكاس لسوء العلاقة ما بـين الطفـل والأب (Parent- Child Relationship) أو مـا بـين الأبوين كـزوجين (As couple) ، وهــا مـن منظور الإرشاد الأسـري، الـذي يتبنى منحسى (النظم الأسرية) (Systems Perspective)، والذي يعني أن إن على جميـع أفراد الأسـرة التكـاتف مـن أجـل إنهاء

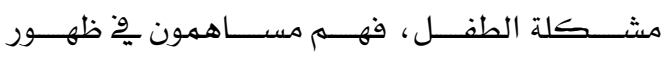

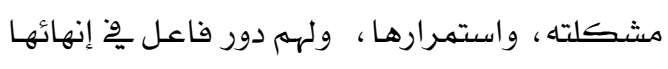

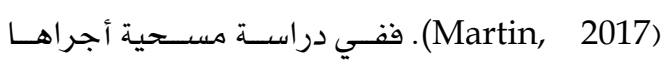
جـيرارد (Gerrard, 2008) على عينـة مـن أطفــال

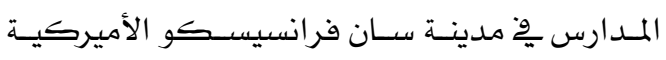
وجـــ أن (10٪) مـن الأطفـال الـذين تتـم إحـالتهم مـن

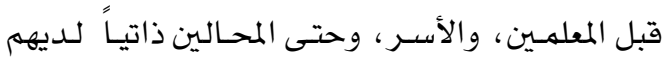

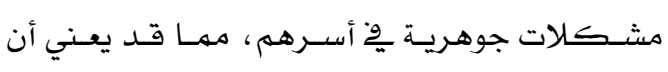

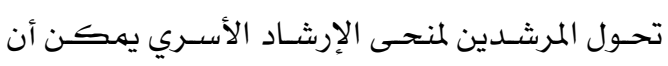

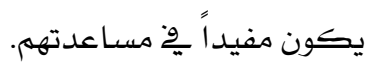

تضـــم المثـــكلات الأســرية المــؤثرة يخ الأطفــال والمـراهقين -كطلبـة - العديـد مــن أشــكال

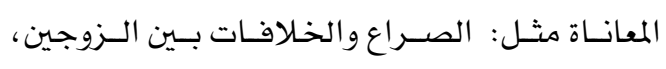


إنّ حركــة البحـــث العلهــي العالميــة الــتي تتعلــق

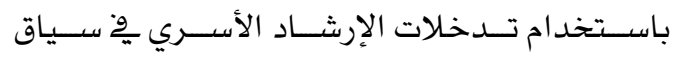

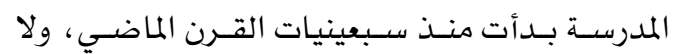

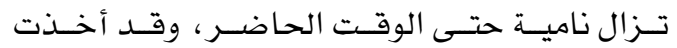
البحــوث عـدة مجــالات للاهتمــام باسـتخدام طـرق البحــث النـوعي والكهـي، منهـا مـا يتعلـق بدراسـة

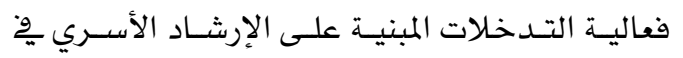
علاج مدى واسـع مـن مشـكـلات الطلبـة مثل دراسـة

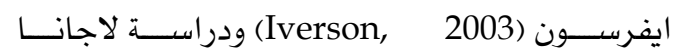
(Mullis ودراسة موليس وادواردز (Lagana, 2004) \& Edwards, 2001)

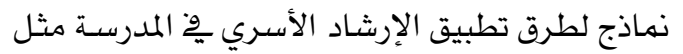
Terry, 2002; Van Velsor \& Cox, دراسـات (2000)

قام كولبرت (Colbert, 1996) بدراسـة هـدفت إلى

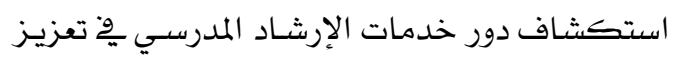

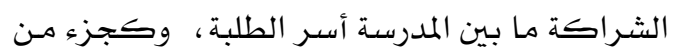
خطة المدرسـة يٌْ الإصـلاح التربوي، أجريـت الدراسـة

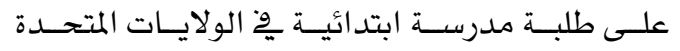

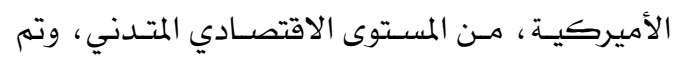

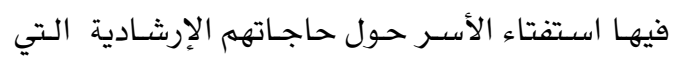
يرغبــون بتحقيقهـا عـبر خــدمات الإرشـاد الأسـري

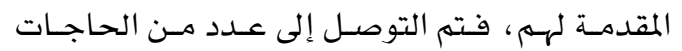

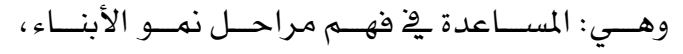
اكتســاب مهــارات تســهم بتحســــن تقـدم أبنـائهم الأكـاديهي وتحصـيلهم الدراسـي، وطـرق التواصـل مع المدرسـة بها يخدم عملية تعلهم الأبناء.

حاول كـل مـن بيروس وجودانف (Perusse \&) oTh Goodenough, 2005

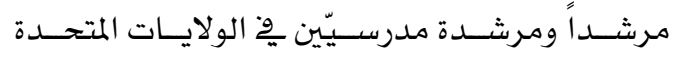
الأميركيـة حـول بـرامج تـدريب المرشـدين وتأهيلههم

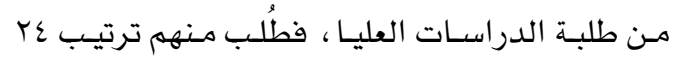

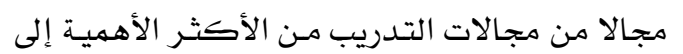
الأقل. تم تصنيف مجال (الإرشاد الزواجي والأسـري) بشــكل عـام ضـهـن المجهـالات الأدنـى. ووهـن النتـائج

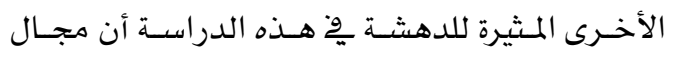

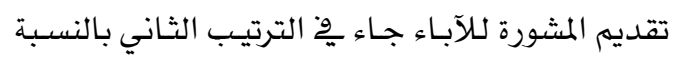

الآخرين هـن أسـرة الطفل فحسبـ، بـل وعلى العهـل

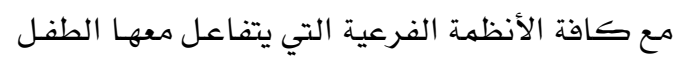

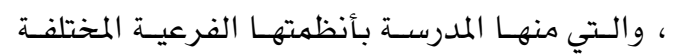

(Paylo, 2011)

ومن التوجهات النظرية يِّ الإرشاد الأسري التي يمكن استخدامها بِ سياق المدرسة من قبل المرشدين المدرسيين (Gerrard, 2008; Sheridan): (الإرشاد الأسـري الآدلري، 2009; Paylo, 2011) والانتقائي و السلوكي والإنساني و الجشطالتي والبنائي والمعربِ السلوكي والاستراتيجي، ولهي

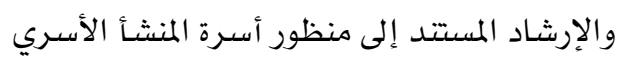
(Family of Origin) ، والتدريب على الوالدية ملدية

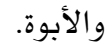
أمـا بالنسـبة إلى طبيعـة التـدخلات الـتي يمكـن مـن

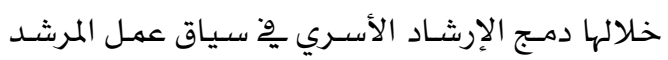

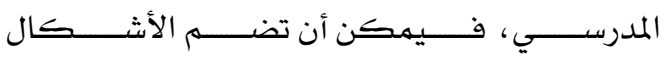
Messin, Kolbert, Hyatt-Burkhart \& الآتيـة

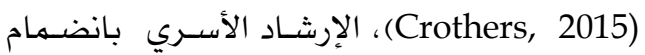

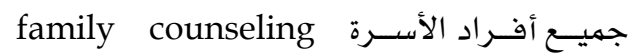

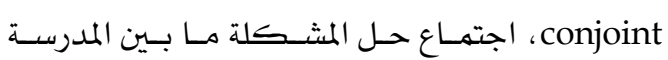
والأســرة Family- school problem- solving

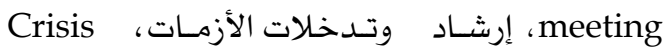
Parent intervention communication training .Parent conference من جهة أخـرى، أشـارت المراجعـة المكثفة الـتي قـام بها جيرارد (Gerrard, 2008) إلى مجموعـة ضـخهمة

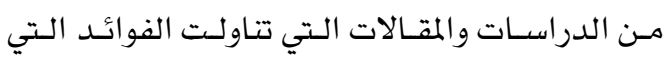

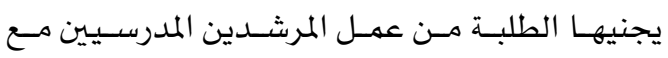
أســرهم بـاسـتخد ام أســاليب مشــتقة مــن الإرشــاد الأســري، وخاصــة مــا يتصــل بصــحتهم النفسـية والاتفعالية، وأدائهم الأكـاديهي، وعـرض توصيات

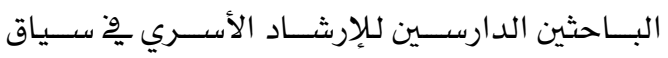

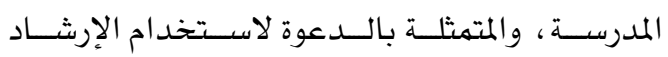
الأسـري كأسـلوب فو إرشــاد الطلبـة ، وباسـتخدام استراتيجياته النهائية والوقائية والعلاجية. 
تضهم العوامل ذات الصلة بالمرشدين انخفاض مستوى

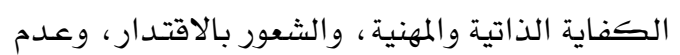

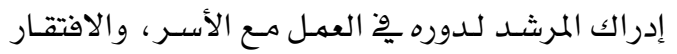
للههارات والتدريب المتخصص لتقديم مثل هذا النوع

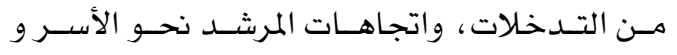

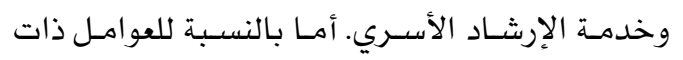

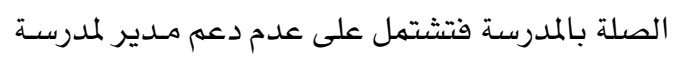

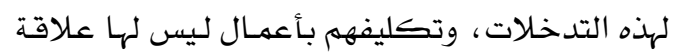
بـأدوارهم المهنيـة كمرشـــين، والجـو الأسـري غـير الودي وغير الداعم، وكثرة الأعباء الملقاة على عاتق

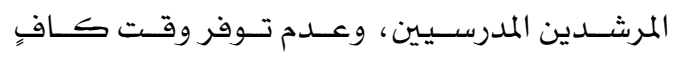
لممارسة خدمات الإرشـاد الأسـري ِِّ سياق المدرسة وِّْ دراسـة استخدمت منهجية البحـث النـوعي قامـت Cook, Bryan \& ) بها كووك وبرايان وبيلفورد على مدار سنتين من تطبيق برناهج (Belford, 2016 للشـراكة المدرسـية ، بـين مدرسـة ابتدائيـة للإنـاث،

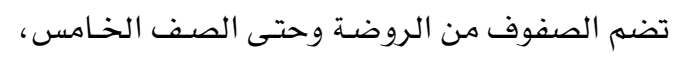

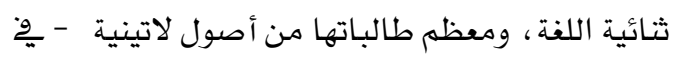

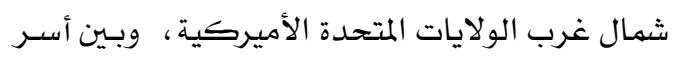
الطالبات، وأسـاتذة وطلبة إحدى جامعات الولايـة. تم

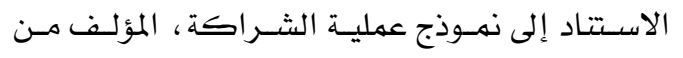

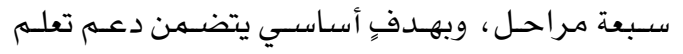

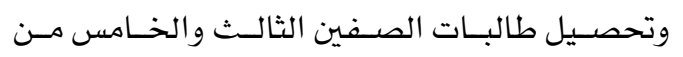

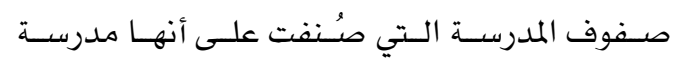
تحصيل طلبتها متـدنٍ، وتحسـين التواصـل هـع الأسـر لخدمة أبنائهم الطلبة. تم تتفيذ مقـابلات شـبه مقنتـة

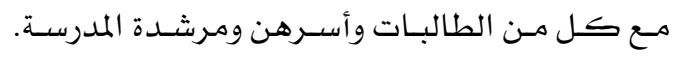
سـت المقابلـة مـع المرشـــة المدرسيـية إلى تقيسيم خبرة

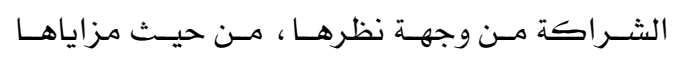

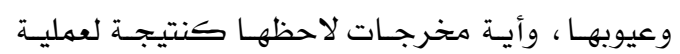
الشـراكة.

أشـارت المرشـدة المدرسية لـدى تحليـل محتوى المقابلـة

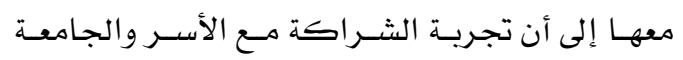

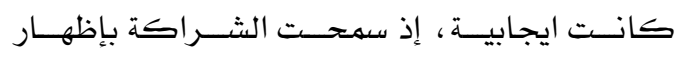

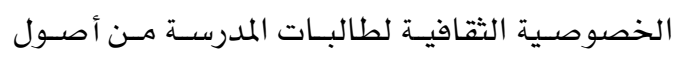
لاتينيـة ، وِخ ممارسـة النشـاطات البدنيـة (مثل دروس البـ
إلى مرشـــي المرحلــة الابتدائيـة ، والترتيـب الثالـث بالنسبة لمرشدي المدرسـة الثانوية ، لقد أقر المرشـدون

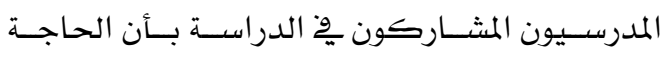

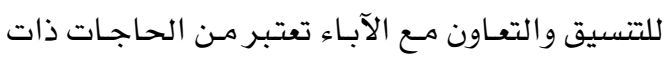
القيمة المرتفعة. عِّ دراسـة قامـت بهـا كـول (Cole, 2012) لتحديـد

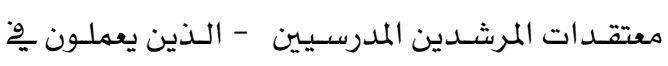
مــارس عســكرية - حـول دورهـم ومســؤولياتهم تجـاه الطلبـة وأسـرهم ، والـتي أجرتهـا بِّ الولايـات

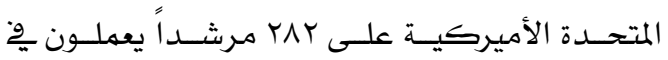

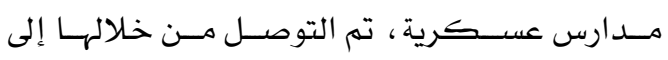

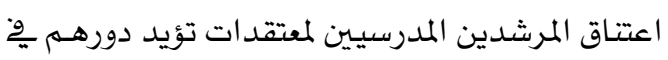

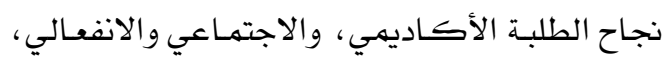

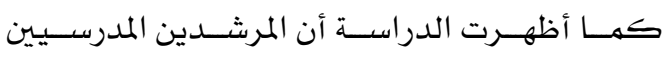

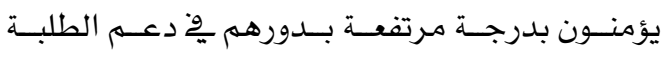

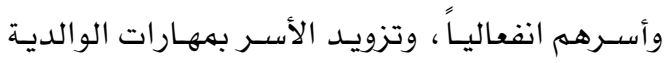
الفعالة ، واستراتيجيات التعامل مع الضفوط النفسية ، وربط الأسـر مع مؤسسـات ومصادر المجتهع. إضافة إلى ما سبقى، ظهرت الحاجة لدراسـة العوامـل

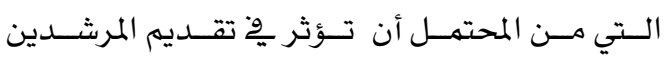

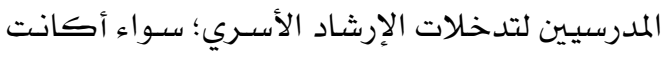

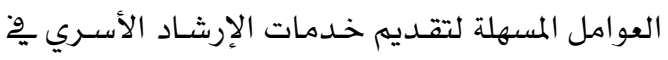

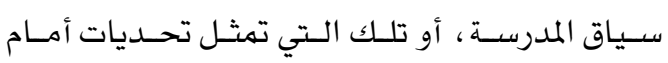

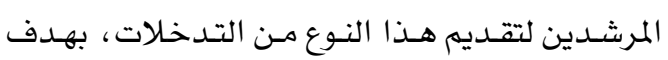

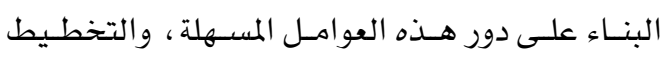
للتدريب المنظم و والمنهج الذي يمكن تقديمه من قبل

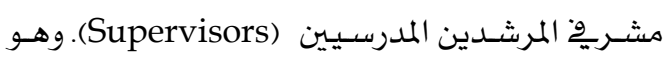

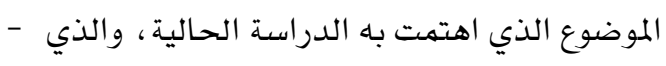

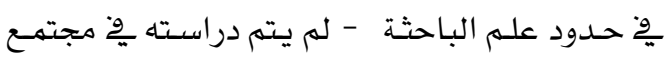

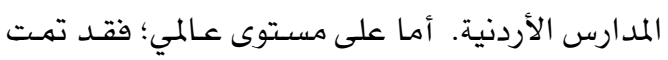

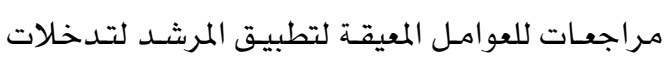

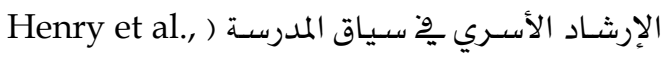
(2017; Bryan \& Henry, 2012 هجموعة من العوامل ذات الصلة بالمرشدين أنفسهم، ومجموعة ثانية من العوامل ذات الصلة بالمدرسـة. 
إلى نتيجـة مفادهـا أنها كلمـا زادت معرفة المرشـدين

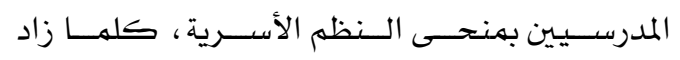

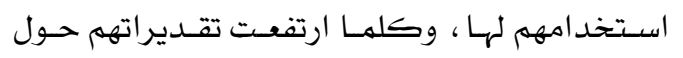
كفايتهم هِّ تطبيقه وِّ سياق المدرسـة. وفيها يتعلق

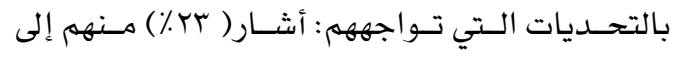

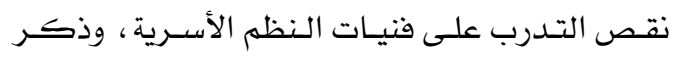

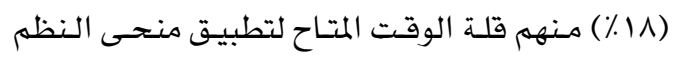

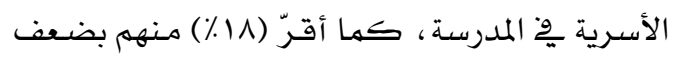

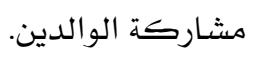

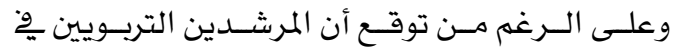

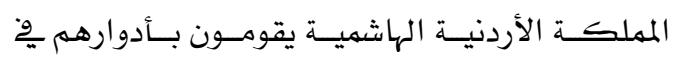

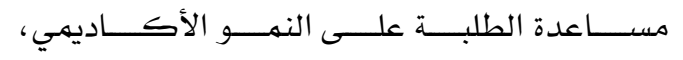

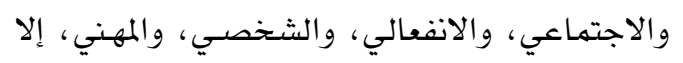

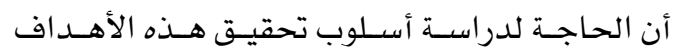

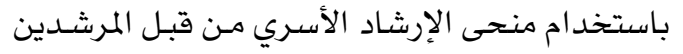

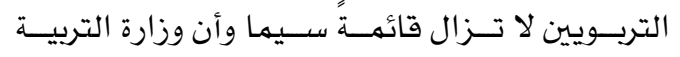

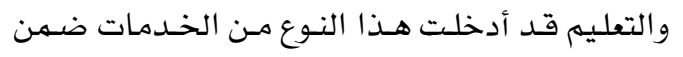

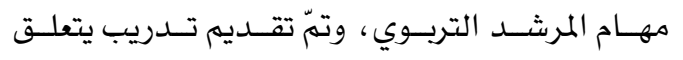

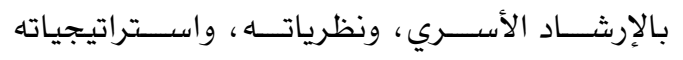

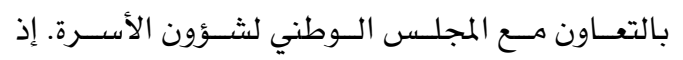

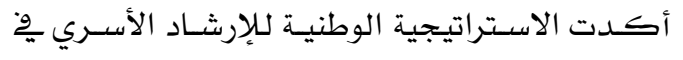

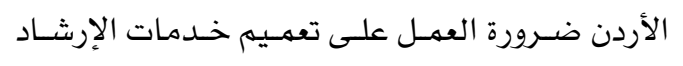

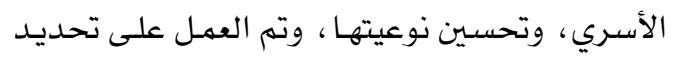

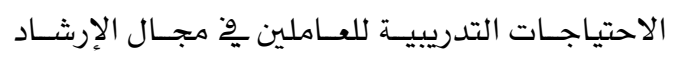

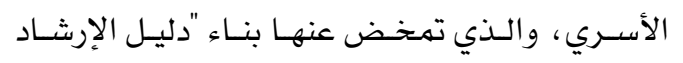

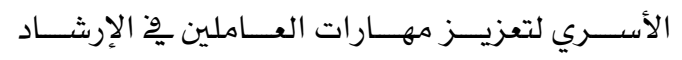

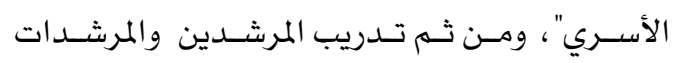

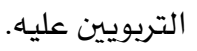

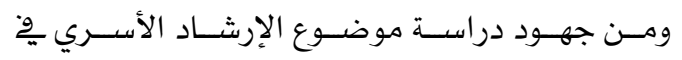
المملكة الأردنية الهاشمية ما قام به المجلس الوطني الأرني

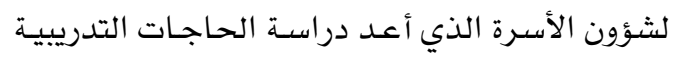

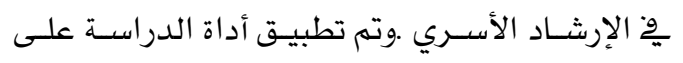

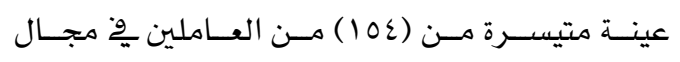

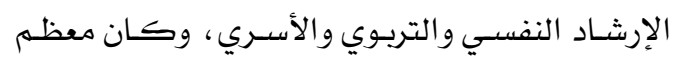

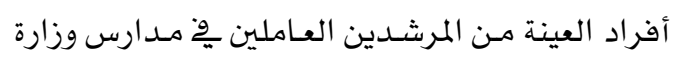

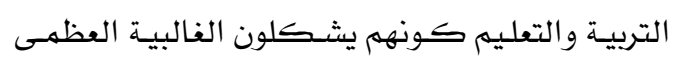

رقصـة السالسـا)، ومنحـت الفرصـة لمناصـرة الأســر

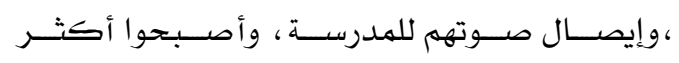

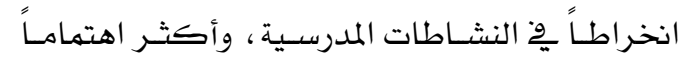
بهتابعة تحصيل بنـاتهم، وتقويـة علاقتهم بالمدرسـة. وشرحت مرشدة المدرسة أيضا عدة تحديات واجهتها

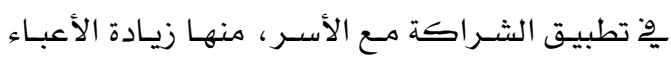

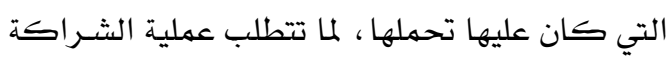

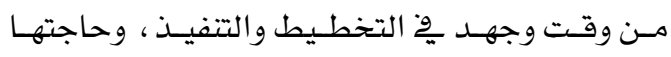

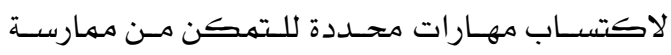

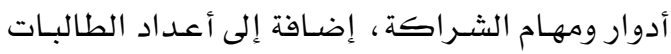
الكبيرة التي عليها خدمتهن. وبِّ دراسـة أخـرى، تم فيهـا الـدمج مـا بـين منهجـي البحث النوعي والكهي، قام دوتي (Dottie, 2017)

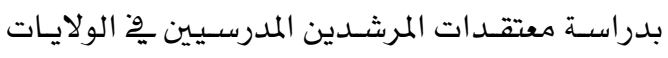

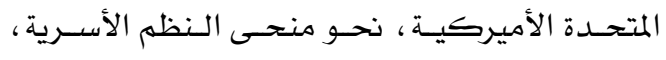

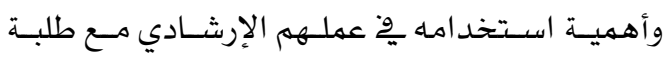

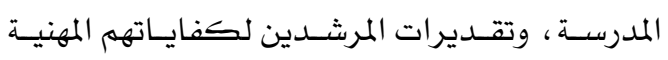

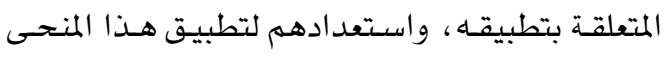

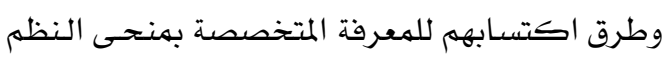

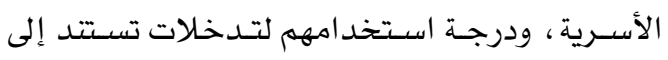

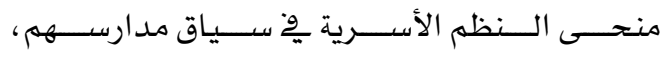
والتحديات التي من المحتمل أن تعيق تطبيقهم لمنحى الني

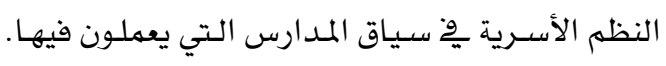

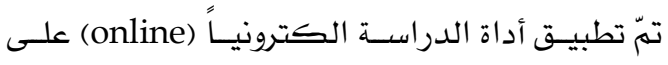

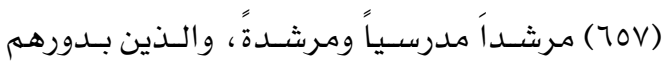
استجابوا ل(07) سؤالاً مفتوحاً ومغلقاً حول القضـايا

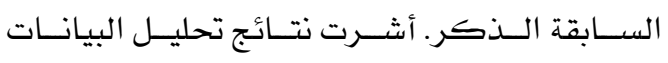

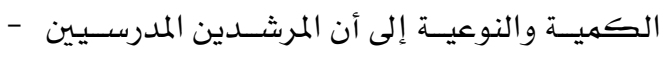

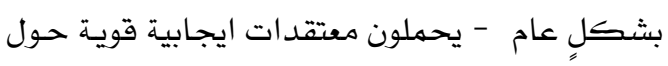

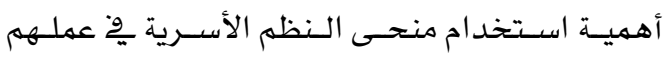

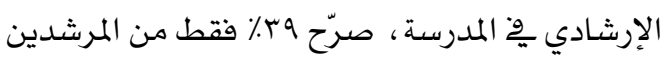

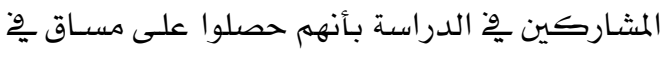

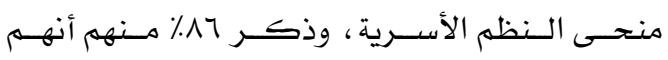

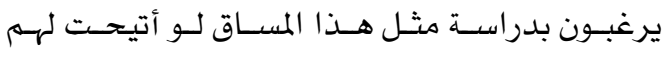

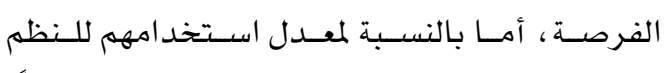

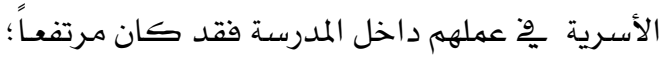

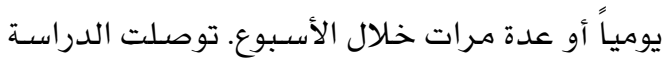




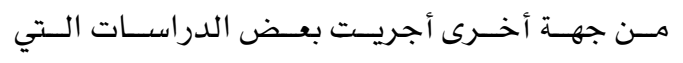

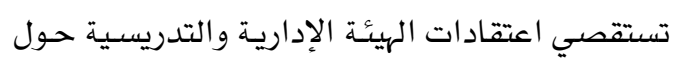

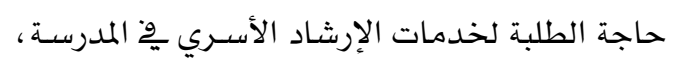

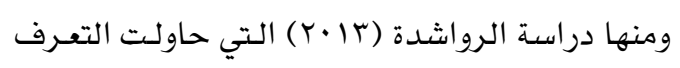
على مستوى إدراك معلمي غرف المصادر ِِّ محافظة

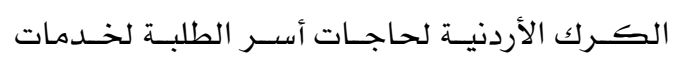

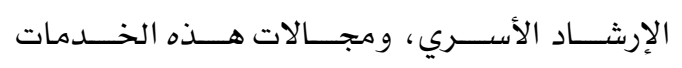
الإرشـادية. طُبقت أداة الدراسـة على عينـة مؤلفـة مـن الإرجن Vo 0

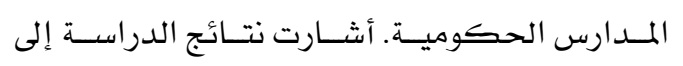

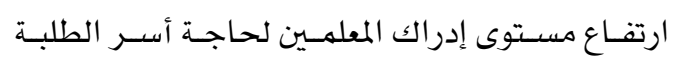

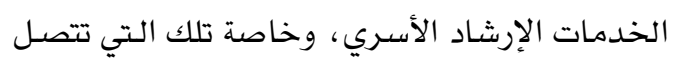

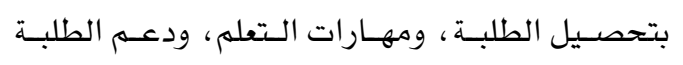
نفسياً وأكاديهياً.

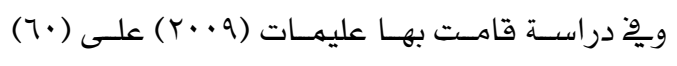

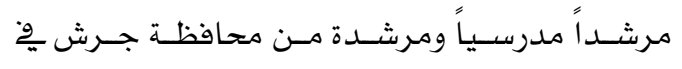

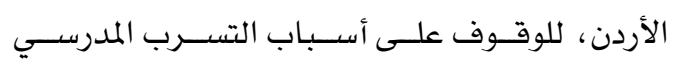

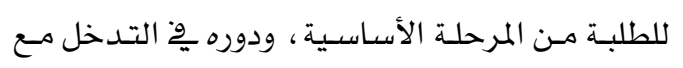

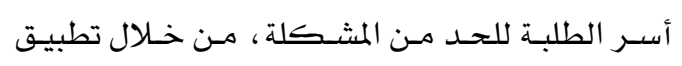

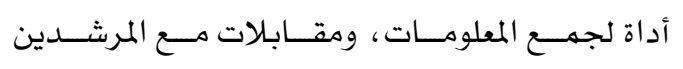

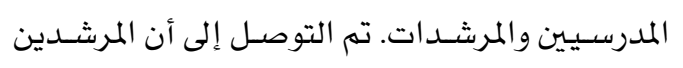

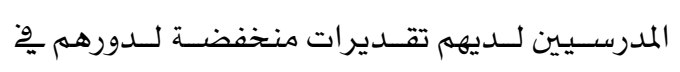

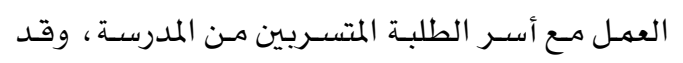

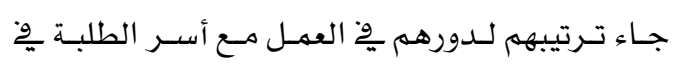

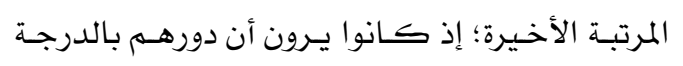

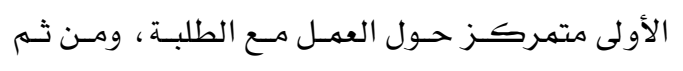

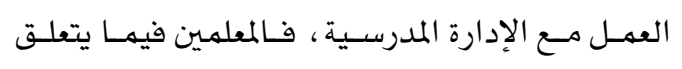

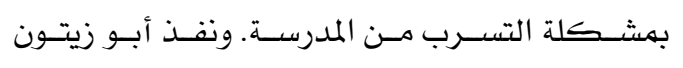
(ع ا ب) دراسة هدفت إلى التعرف على مدى مهارسـة

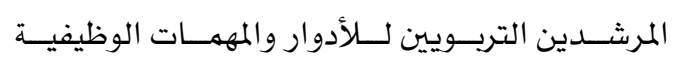

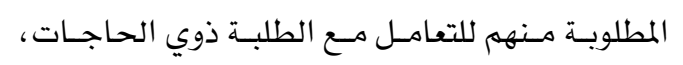

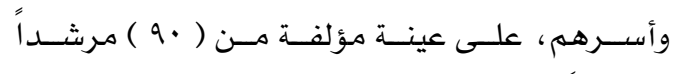
ومرشدةً من مدارس وزارة التربية والتعليهم يِّ الأردن. أشارت نتائج الدراسـة المتعلقة بدور المرشد التربـوي

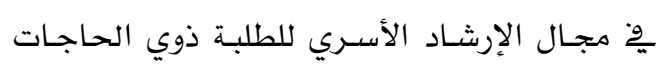

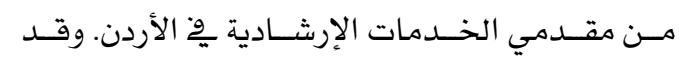

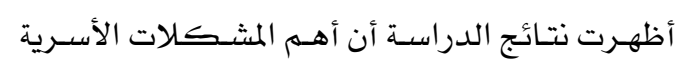

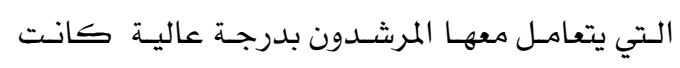

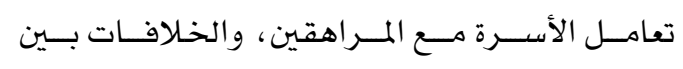

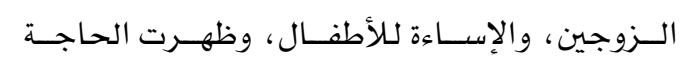

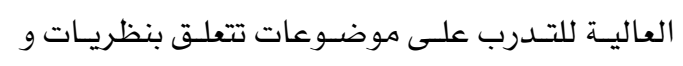

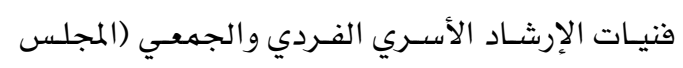

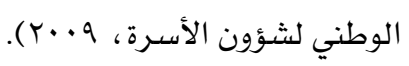
كهـا أجــرت العتـوم (ع · ·r) دراسـة حـول الحاجـة للإرشـاد الأسـري مـن وجهة نظر المرشـدين التربويين

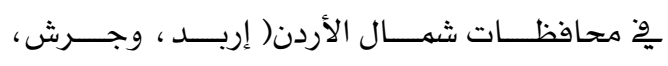

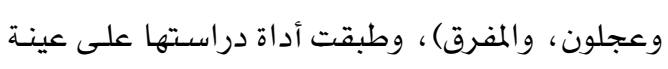

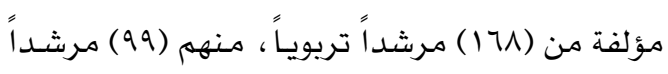

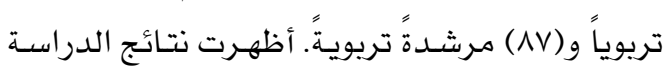

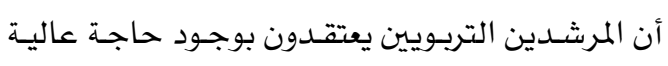

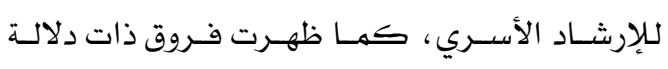

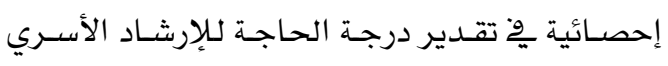

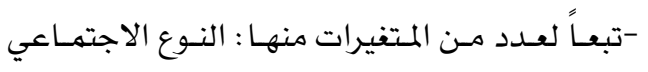
وذلك لصالح المرشدين الذكور، على مـتغير الخبرة ولصـالح فئسة (أقل مـن م سـنوات خبـرة) ، وله تظهـر

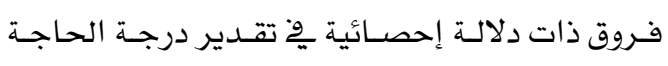
للإرشاد الأسري تبعا لمتغير المؤهل العلمي.

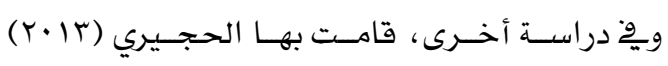
للتعـرف إلى درجـة ممارســة المرشـــ التربـوي للإرشــاد

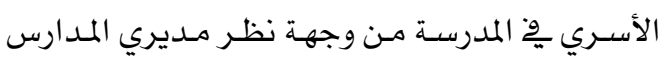

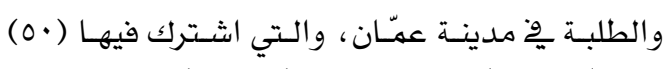

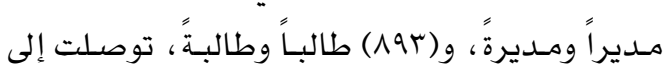

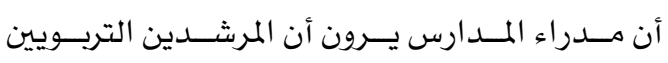

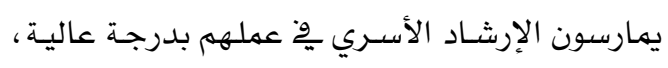

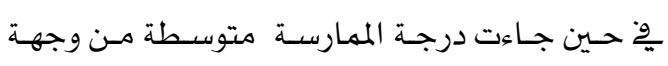

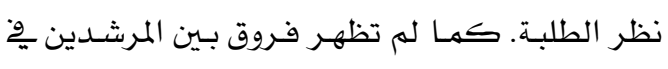

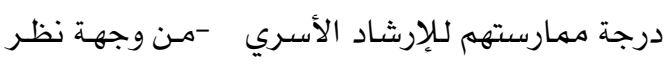

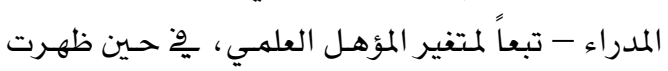

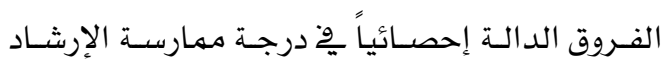

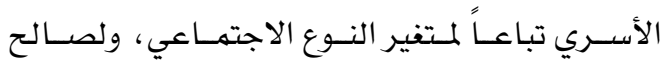

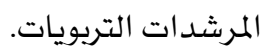


نحوهــا ، والعوامـل الـتي تعرقـل اسـتخدـامهم لهـذهـ

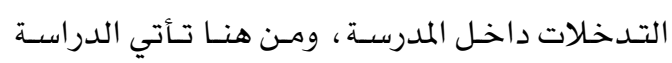
الحالية كهماولة للمسـاهمة ِِّ دراسة هـذا الجانب مـن عمـل المرشـــين المدرسـيـين - والـــي لا يـزال

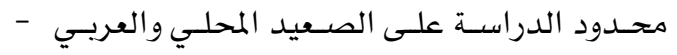
وذلك مقارنة بالدراسـات الواسعة والمتعلقة بالمرشـدين

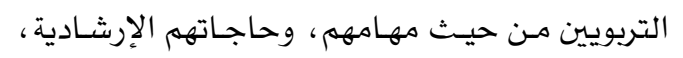

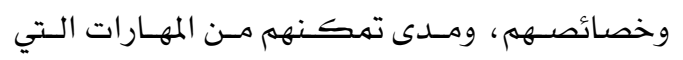

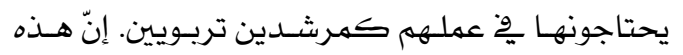
الدراسـة تهثـل محاولـة لتسـليط الضـوء علـى درجـة توظيف المرشد المدرسي تدخلات الإرشاد الأسـري مِّ

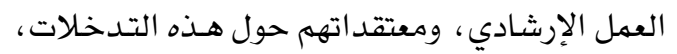

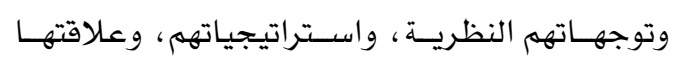
بعض المتفيرات ذات الصلة.

\section{أسئلة الدراسة}

تسعى الدراسة إلى الإجابة عن الأسئلة التالية: • هـل يسـتخدم المرشـدون المدرسـيون تـدخلات

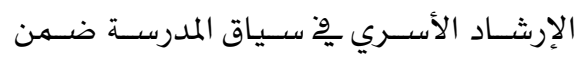

الخدمات التي يقدمونها لطلبة مدرستهم؟ الهرئ r. مـا التوجهات النظريـة التي يتبناهـا المرشـدون

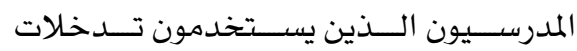
الإرشـاد الأسـري پِّ سياق المدرسة ؟ r. مــا اعتقــادات المرشــدين المدرسـيـين حسول

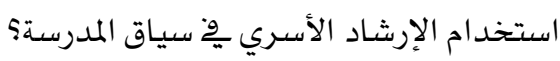
ع. مــا درجــة اســتعد اد وجاهزيــة المرشــــين المدرسيين لتطبيق تـدخلات الإرشـاد الأسـري بِّ سياق المدرسة 0. ما التحديات التي تواجه المرشدين المدرسيين لتطبيـق تـدخلات الإرشـاد الأسـري ـوْ سـياق

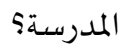

الخاصـة إلى أنهـم يمارسـون هـــه الأدوار والمههـات الوظيفية المتوقعة منهم بدرجة متوسطة. ووــن الدراسـات العربيـة حـول معتقـــات المرشــدين

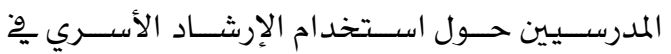

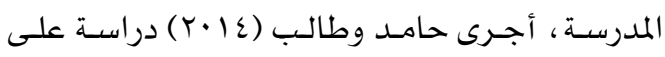

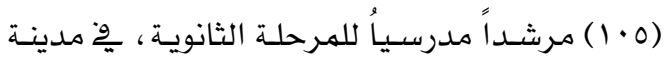

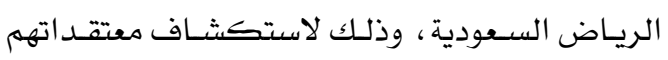

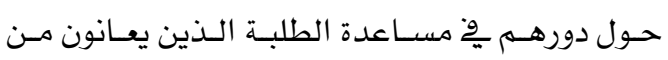
العنف الأسـري. أظهـرت نتـائج الدراسـة أن المرشـدين المدرسيـين لديهم درجة متوسـطة مـن الاعتقـاد بوجـود المري

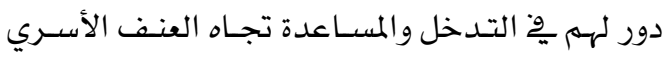

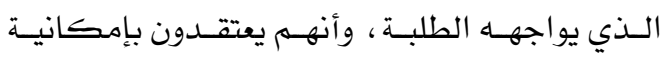

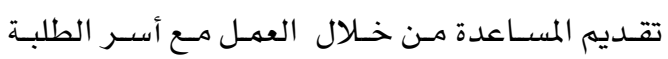
الذين يتعرضون للعنف الأسـري، باسـتخدام نشـرات

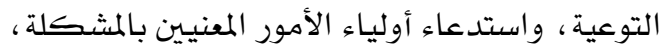
والزيارات المنزلية ، ولقاءات التوجيه الجمعي لأولياء

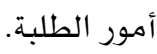
مـن ناحيــة أخـرى ، فـإن تحليـل الدراسـات المتعلقــة

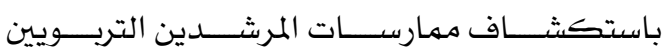
لتــدخلات الإرشــاد الأســري، ودرجــة امـتلاكهم للمهارات اللازمة لتطبيق هذا النوع من طرق العهل، ، وتوجهاتهم النظريـة، واسـتراتيجياتهم تظهـر أن هـذا

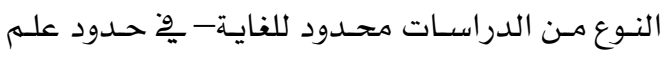

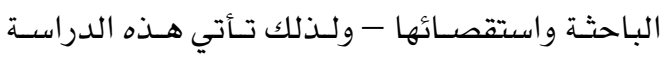
كخطوة أولية باتجاه استقصاء مسـاهمات المرشدين التربويين يٌْ تقديم الإرشـاد الأسـري يِّ المـدارس التي يعملون بها.

\section{مشكلة الدراسة}

على الـرغم مـن تزايــ الـدعوات العالميـة الـتي تثـــع المرشـدين المدرسيـين على استخدام تـدخلات الإرشـاد

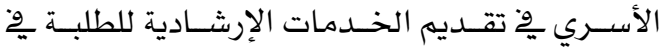
المدرسـة (Dottie, 2017; Henry et al., 2017)، إلا لاهي

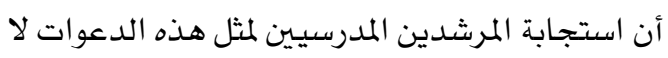

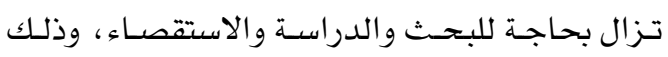

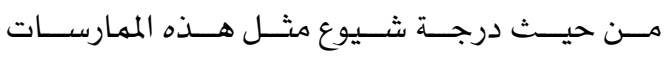

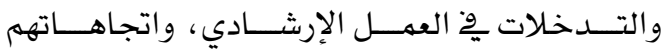


البيـت والمدرســة ، مهــا يعـني أنّ المـكاسـب الـتي

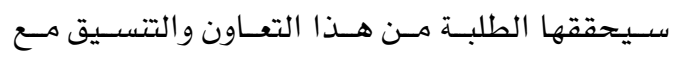

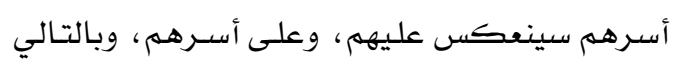

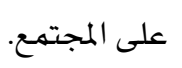

\section{مصطلحات الدراسة}

الإرشـاد المدرسبي (School Counseling) : عبـارة

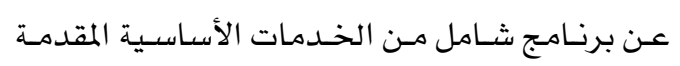

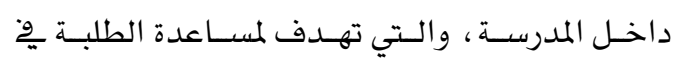
تحقيق النهـو النفسي والأكـاديهي والمهني، وتـوفر لهم فرصاً لتسهيل نهـوهم وتمـتعهم بالصـحة النفسية الصية (Kim, Mayes, Hines, \& Bryan, 2017, p:1) الإرشـاد الأسـري (Family Counseling): يشـير

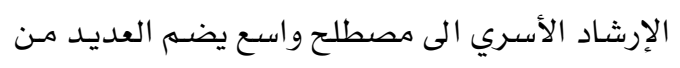

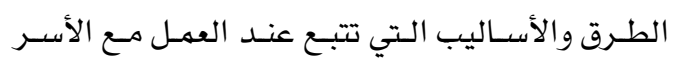
التي تعاني من صعوبات نفسية واجتماعية ، وقـد بـرز

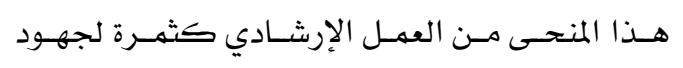

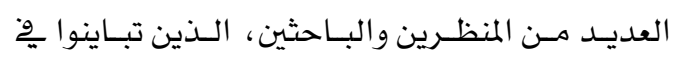

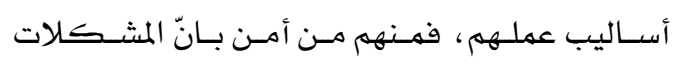

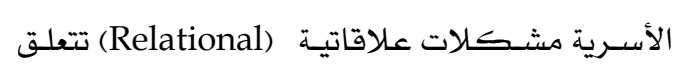

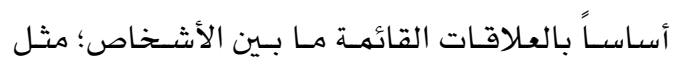
(الانصهار ، وضعف تهـايز الـات، وظهور المثلثات،

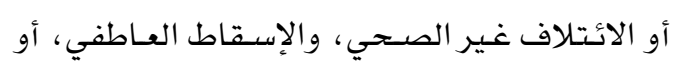

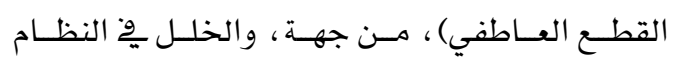

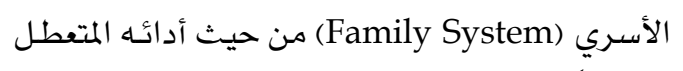

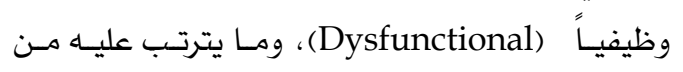

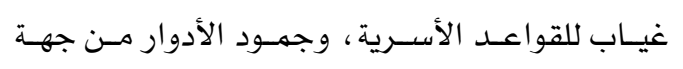
أخرى (Messin et al., 2015, p: 278).

\section{School (تدخلات الإرشاد الأسري بِ سياق المدرسة}

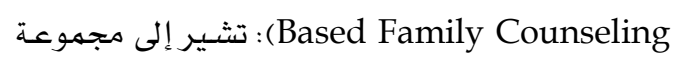

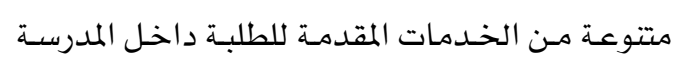

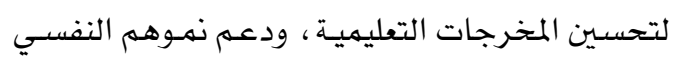

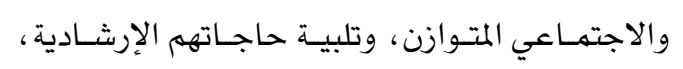

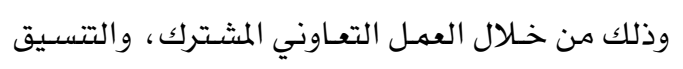

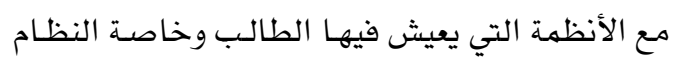

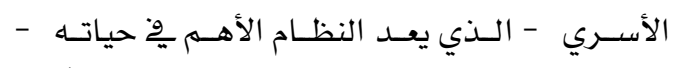

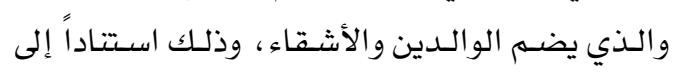

\section{أهداف الدراسة}

$$
\text { تهدف هذه الدراسـة إلى: }
$$

التعـرف علـى درجـة اسـتخدام المرشــدين

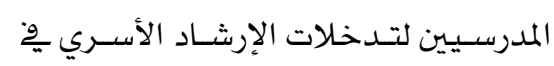
سـيـاق المدرسـة ، والتوجهـات النظريـة الـتي يتبنونها.

استقصــاء معتقـــات المرشـدين المدرسـيين حـول اسـتخدام الإرشـاد الأسـري ِِِّ سـياق المدربسة

التعـرف علـى درجــة اسـتعد اد وجاهزيــة المرشــــين المدرســيـين لتطبيــق تــدخلات الإرشاد الأسري يخّ مدارسهم.

استـكشـاف العوامل الـتي تتحـدى توظيف

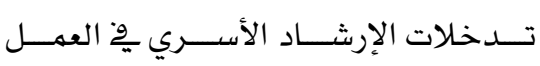

$$
\text { الإرشادي المدرسي. }
$$

\section{أهمية الدراسة}

للدراسـة الحاليـة أهميتـان، نظريـة وعمليـة تطبيقيـة؛ حيـث يهكن توضـيح الأهميـة النظريـة للدراسـة مـن تركيزهـــا علـى موضـــوع مهـــم يتعلــق باســتخدام

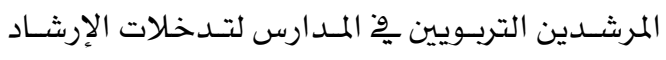

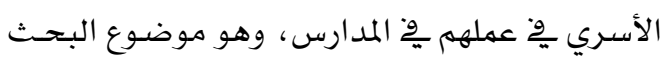

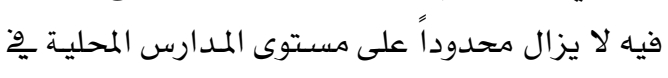

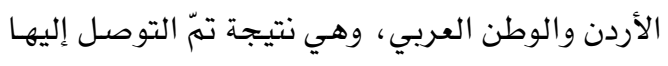
بعـد العـودة إلى قواعـد البيانـات الإلكترونيـة وموقع

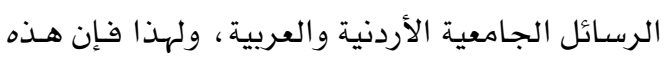
الدراسـة يتوقع أن تثري المكتبـة العربيـة ، وأن تهثل

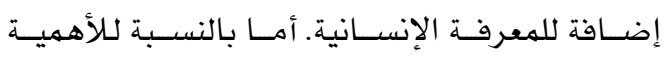

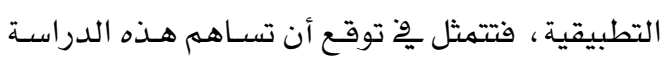

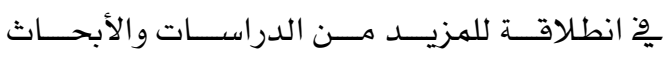

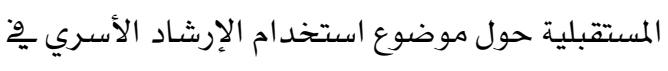

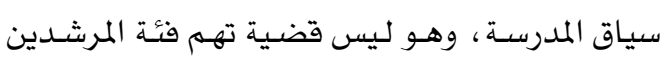

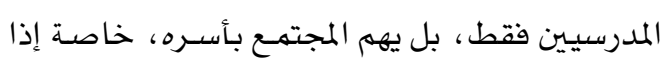

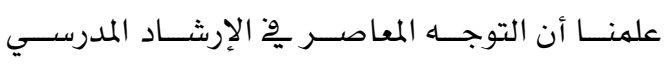
يتضـــن التأكيـد علـى الثــراكة والــدمج مـا بـين 
التحديات (Challenges) : الصعوبات التي يدركها

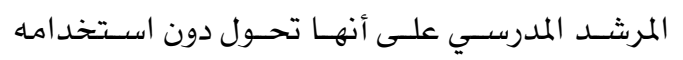

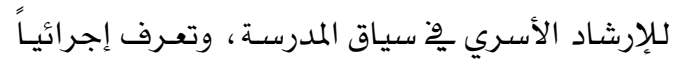

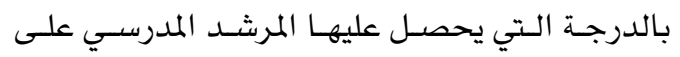
الفقرات الني تقيس تحديات تطبيق الإرشاد الأسـري لمئي وِِّ سياق المدرسة.

\section{حدود الدراسة و محدداتها}

تتمثـل حـدود الدراســة الزمانيـة بفـترة تطبيـق أداة

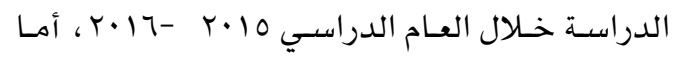

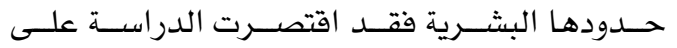

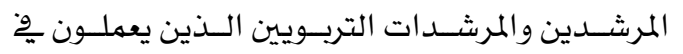

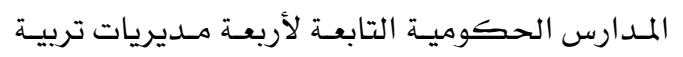

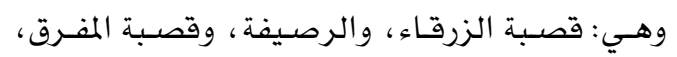

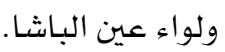

أمــا بالنســبة لمحــددات الدراسـة الحاليــة فتتهثـل

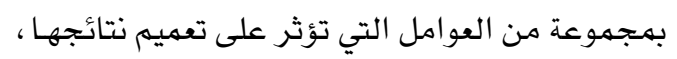

1. الأداة المستخدمة وِّ الدراسة ، وأسلوب قياس

\section{متفيراتها.}

r. طريقة اختيار أفراد الدراسة ، ودرجة تهثيلهم

$$
\text { لمجتهـع المرشدين التربويين. }
$$

r. يتحـد تعميم نتائج الدراسة خـارج مجتمعها

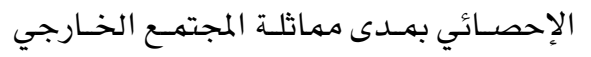

$$
\text { لمجتمع الدراسة الحالي. }
$$

\section{الطريقة والإجراءات}

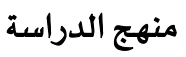

تم تطبيق المنهج الوصفي ِّْ هـذه الدراسـة، لكونـه

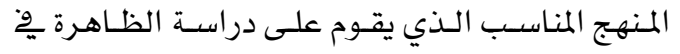

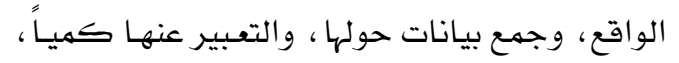

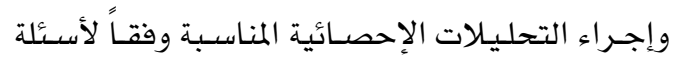

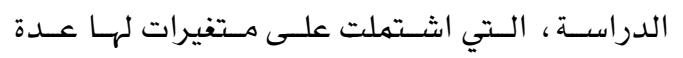

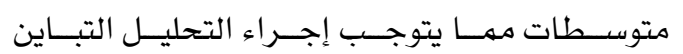
المشـترك، إضـافة لاسـتخر اج المتوســطات الحســابية والانحرافات المعيارية والنسب المئوية.

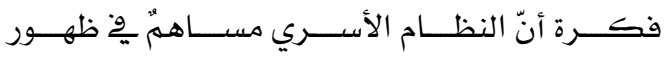

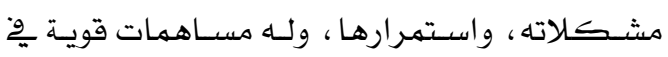

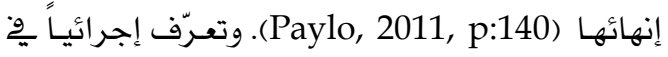

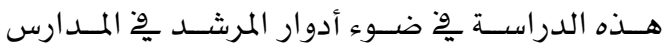

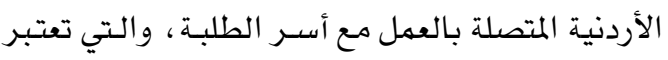

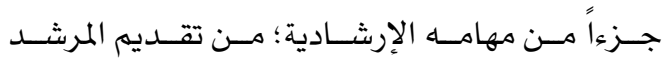

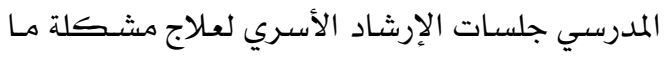

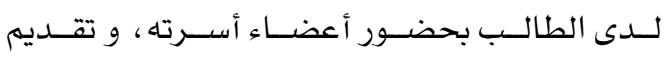

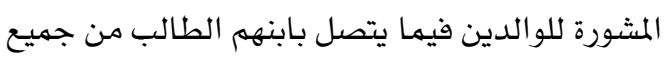

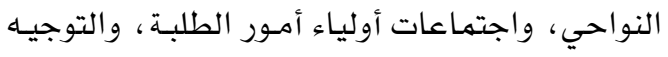

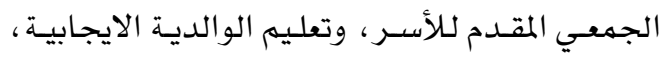

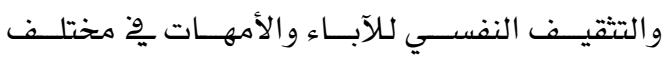

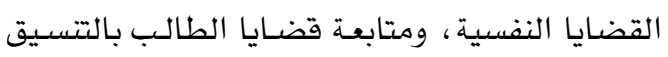

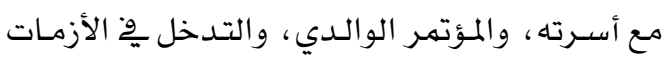

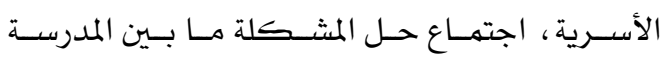

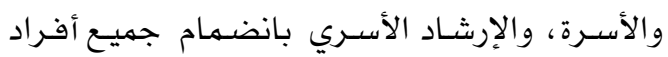

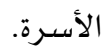
in family ) التوجهات النظرية فِّ الإرشاد الأسـري :) Counseling Theoretical Orientation تتضمن مجموعة واسـعة مـن النظريات التي صممت

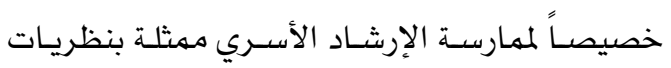

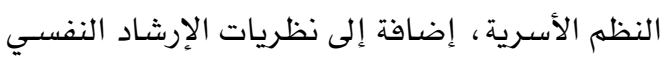
التي لها تطبيقـات مـع الأسـر (Gerrard, 2008).

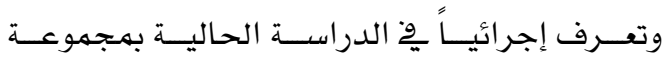

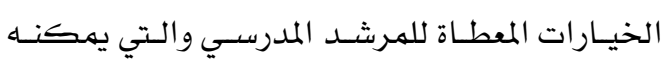

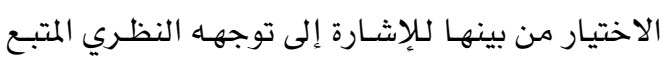

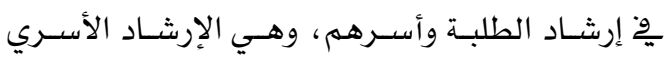

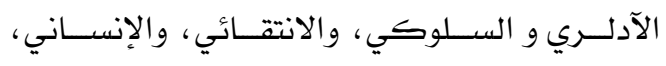
والمعربِّ السلوكي والنظم الأسرية. المعتقدات (Beliefs) : مجموعة الأفكار التي يحملها

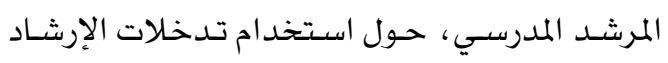

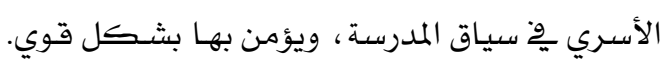

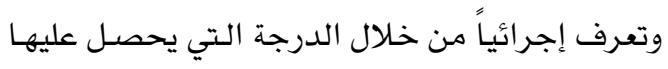

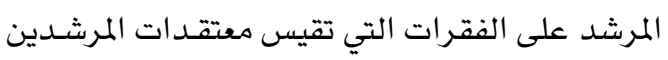

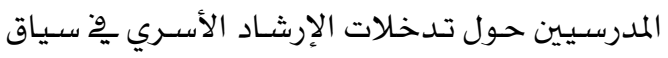
المدرسة المستخدم يوّ الدارسة الحالية. 


$$
\begin{aligned}
& \text { تكـونـت أداة الدراسـة مـن عـدة أجـز اء علـى النـحـو }
\end{aligned}
$$

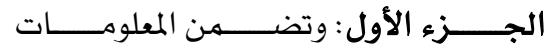

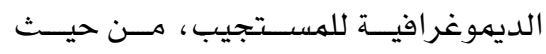

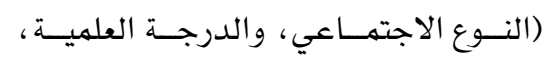

$$
\begin{aligned}
& \text { وحجم المدرسة). }
\end{aligned}
$$

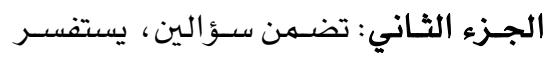

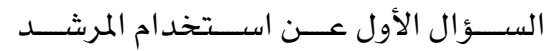

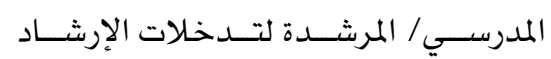

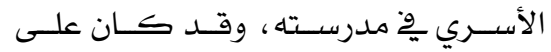

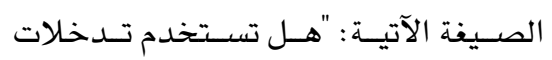

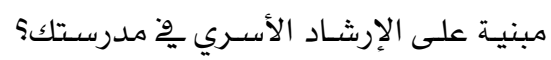

$$
\begin{aligned}
& \text { بحيث يستجيب المرشد المدرسي/ المرشـدة } \\
& \text { بأحد الخيارين: نعم أو لا؟ }
\end{aligned}
$$$$
\text { أمـا السـؤال الثاني، : فيتصـل بالطلب مـن المرشـــين }
$$

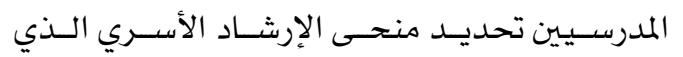$$
\text { يستخدمونه - - وْ حسال كانـت إجـابتهم بـنعم على }
$$

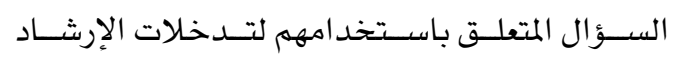$$
\text { الأسـري ِِّ سياق المدرسـة - وذلك بالاختيار مـن بـين }
$$$$
\text { قائمة من نظريات الإرشاد الأسـري، وهي: }
$$$$
\text { • الإرشاد الأسري الآدلري }
$$$$
\text { الإرشاد الأسري الانتقائي }
$$$$
\text { الإرشـاد الأسري السلوكي }
$$$$
\text { الإرشاد الأسـري الإنساني }
$$$$
\text { الإرشاد المستتد إلى النظم الأسرية }
$$$$
\text { الإرشاد الأسري المعرِِّ السلوكي }
$$

الجـزءء الثالـث: تضــمن هـــا الجـزءء (ro)

فقـرة، مقســـة إلى ثلاثـة مجـالات تـرتبط

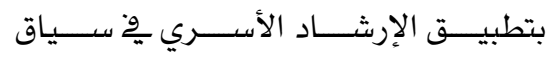

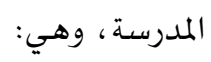

المجــال الأول : معتقـــات المرشـــين المدرسـيـين حـول

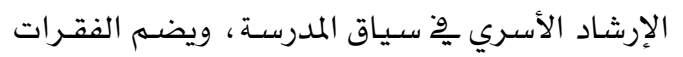

$$
\text { من } 17 \text { - } 17 \text { من فقرات المقياس. }
$$

\section{أفراد الدراسة}

تم تطبيـق أداة الدراســة علـى عينــة مــن المرشـــين

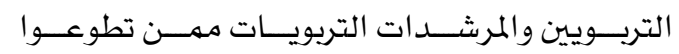
للاسـتجابة على أداة الدراسـة ، اشـتملت على (91)

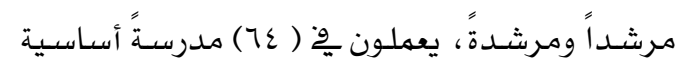

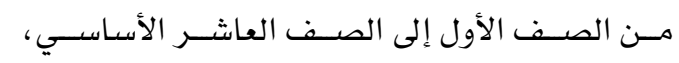

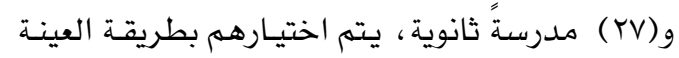

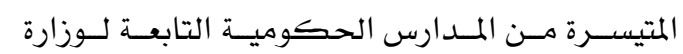

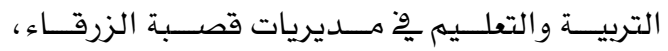
والرصيفة، وقصبة المفرق، ولواء عين الباشا ، وذلك

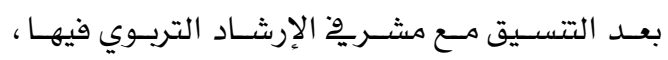
والـــين قـاموا بتوزيـع أداة الدراسـة علـى المرشـــين

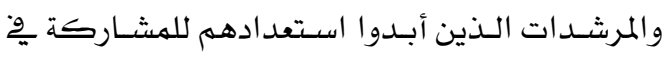
الدراسـة بشكلٍ طوعيّ. ويبين جـدول ا الخصـائص

\begin{tabular}{|c|c|c|c|}
\hline النسبة & 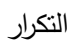 & الفئات & المتغير \\
\hline $00, \varepsilon$ & $1 \leq$ & ذكر & النوع \\
\hline$\wedge \varepsilon, 7$ & VV & أنثى & الاجتماعي \\
\hline $91, r$ & זی & بكالوريوس & الدرجة العلمية \\
\hline$\wedge, \wedge$ & $\wedge$ & ماجسنير & \\
\hline Tr,v & $0 \wedge$ & أقل من ه سنوات & سنوات الخبرة \\
\hline \multirow[t]{2}{*}{$1 V, T$} & 17 & من 0-. & \\
\hline & & سنوات & \\
\hline \multirow[t]{2}{*}{ 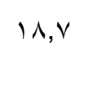 } & iv & أكثر من · & \\
\hline & & سنوات & \\
\hline$v_{\bullet}, \varepsilon$ & $7 \varepsilon$ & أساسية & نوع المدرسة \\
\hline$r q, 7$ & tr & ثانوية & \\
\hline$r V, O$ & ro & أقل من . . & حجم المدرسة \\
\hline $0 \wedge, r$ & r & $1 \ldots-0 \ldots$ & \\
\hline $1 \leq, r$ & ir & أكثر من ... & \\
\hline$\% 1 \ldots$ & 91 & المجموع & \\
\hline
\end{tabular}
الديهوغرافية للمشاركين يِّا الدراسـة.

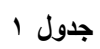

الخصائص الايموغرافية لأفراد الاراسة (ن= الو ج)

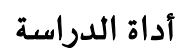

قامـت الباحثة ببنـاء مقيـاس " الإرشـاد الأسـري ِوِ

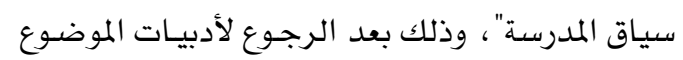
(Carter \& Evans, 2008; Crespi \& Hughes, 2004; Griffin, \& Steen, 2010; Snyder, 2010) 
معامل الاتساق الداخلي حسب معادلة كرونباخ ألفا، ويبين جدول r أدناه هذه المعاملات، واعتبرت الماتي

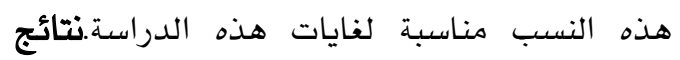
الدراسة ومناقشتها الســؤال الأول: للإجابـة عـن الســؤال الأول: "هــل

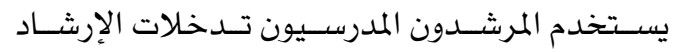

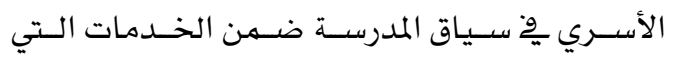

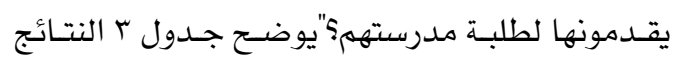
التي تم التوصل إليها.

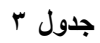

التكرار والنسبة المئوية لاستخام تدخلات مبنية على النى الإرشاد الأسري في سياق الدرسية لإنة

\begin{tabular}{|c|c|c|}
\hline النسبة المئوية & التكرار & لإجابة \\
\hline$\% \vee 9,1$ & VT & نعم \\
\hline$\% r \cdot, q$ & 19 & $y$ \\
\hline$\% 1 \ldots$ & 91 & المجموع \\
\hline
\end{tabular}

يتضح من جدولr أن V9,1 \% من المرشدين المدرسيين صرحوا بأنهم يستخدمون تدخلات اندات

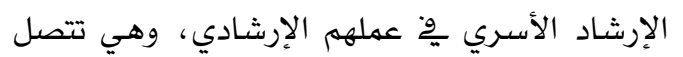
بالأدوار المنصوص عليها من قِبل وزارة التربية

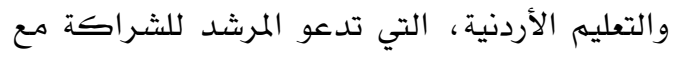
الأسر، والتنسيق معها بكافة السبل المتاحة

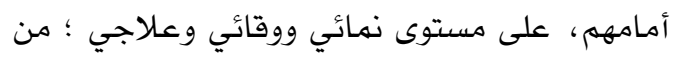

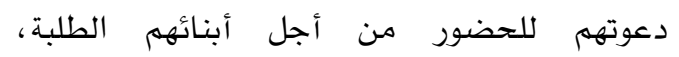

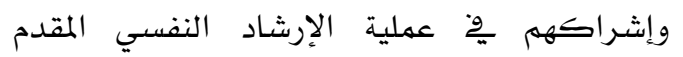
لأبنائهم الطلبة، وانضمامهر للجلسات الإرشادية

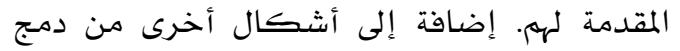

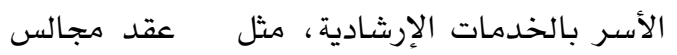
الآباء والأمهات، وتتظيم اللقاءات الجماعية بالأسر

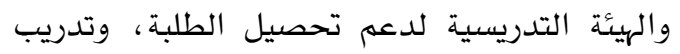

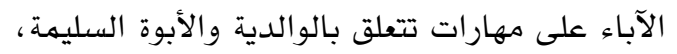
وغيرها من مهارات الحياة الأسرية، ومتابعة شؤون الطلبة المتعثرين دراسياً، والموهوبين والمتفوقين

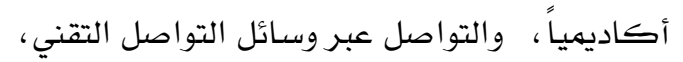
من أجهزة محمولة وهواتف وبريد الكتروني،

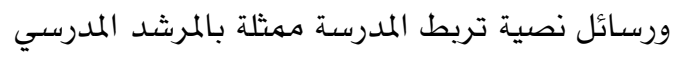
وأسر الطلبة (أبو زيتون، عاب()). تتسق نتيجة
المجال الثاني: استعداد أو جاهزية المرشدين

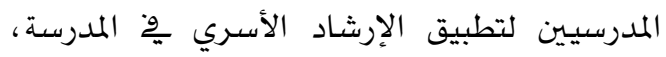
ويضم الفقرات من VV - IV من فققرات المقياس. المجال الثالث: تحديات تطبيق الإرشاد الأسري ِِّ سياق المدرسة ، ويضم الفقرات من لro- TV. يستجيب المرشد التربوي على فقرات هذا المقياس

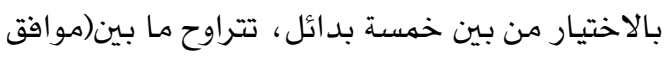

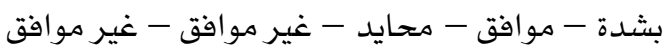
بشدة)، وبناء على هذا التدريج الخماسي، فإن

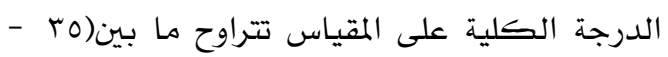

( ) Vo صدق أداة الدراسة: لقد تم العمل على استخراج دلالات صدق المحكمين للأداة من خلال عرضها

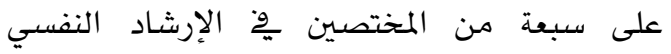

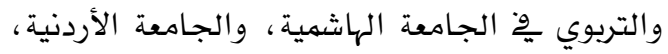

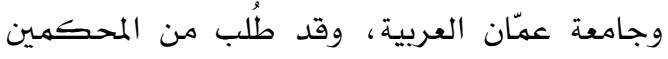
تقييم سلامة الصياغة اللفوية، وانتماء الفقرات للمقياس، تم اعتماد نسبة اتفاق (•^ر••) كمعيار لقبول الفقرة، وبعد الاطلاع على آراء المحكمين الني كانت ايجابية لمُتستبعد أي فقرة من الفقرات

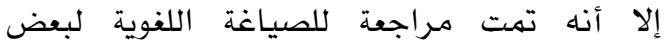

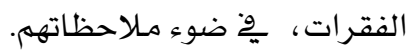

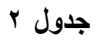

معامل الاتساق اللاخلي كرونباخ ألفا لمقياس الإرشاد

\begin{tabular}{|c|c|}
\hline \multicolumn{2}{|c|}{ الأسري في سياق المدرسة } \\
\hline الاتساق الداخلي & المجالات \\
\hline \multirow[t]{2}{*}{,$\wedge \wedge$} & معتقدات المرشدين التزبويين حول \\
\hline & الإرشاد الأسري في سياق المدرسة \\
\hline \multirow[t]{3}{*}{,$\wedge$} & استعداد أو جاهزية المرشدين \\
\hline & التربويين لتطييق الإرشاد الأسري \\
\hline & في سياق المدرسة \\
\hline \multirow[t]{2}{*}{ 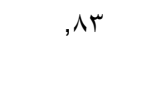 } & تحديات تطبيق تدخلات الإرشاد \\
\hline & الأسري في سياق المدرسة \\
\hline,$\wedge 9$ & المقياس ككل \\
\hline
\end{tabular}

ثبات أداة الدراسة: أما بالنسبة إلى دلالات ثبات

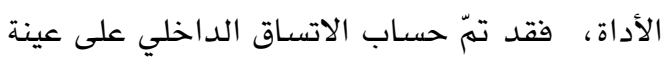

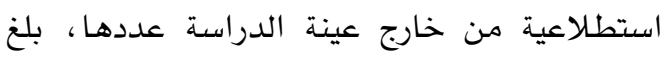

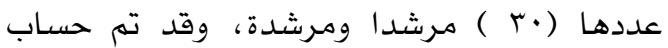


يتضنح من جدول ع أن الإرشاد الأسري السلوكي

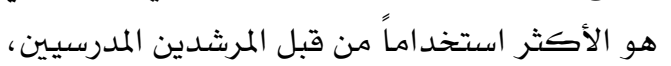

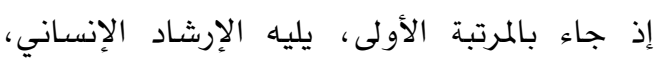
فالإرشاد المعريخ السلوكي، وجاء الإرشاد

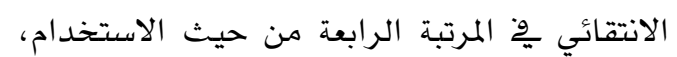

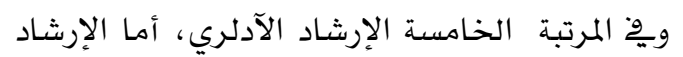

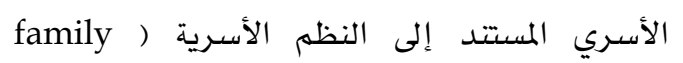

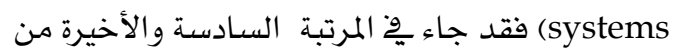

حيث الاستخدام.

ويمكن عزو هذه النتائج المتصلة بالاستخدام الأعلى للنظرية السلوكية كونها من النظريات التي يتلقى عليها المرشدون المدرسيون تدريباً منظماً خلال فترة

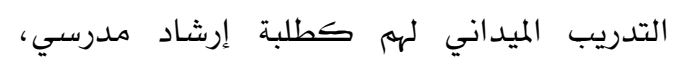
ولاحقاً بعد التحاقهم بالمهنة ، كها أنها تساعد لمدان

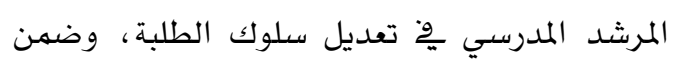

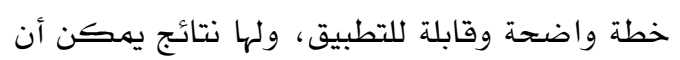

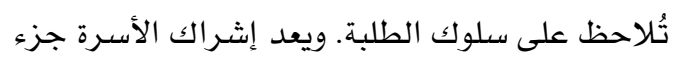
مهماً من الكثير من برامج تعديل السلوك، والذي

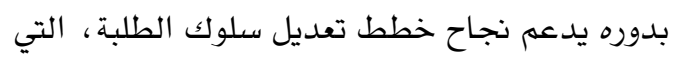

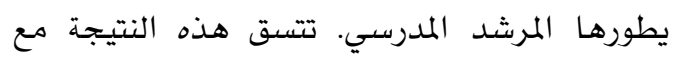

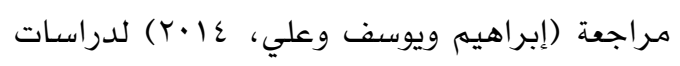
سابقة تشير إلى شيوع استخدام النظرية السلوكية ِّْ تقديم تدخلات وبرامج إرشادية لعينات متتوعة من الأطفال والمراهقين من سن المدرسة، وتقديم

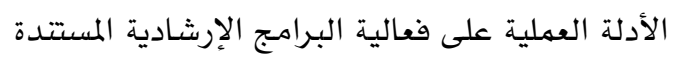

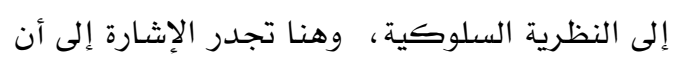
نتائج الدراسة الحالية تتفق والنتائج التي تم التوصل

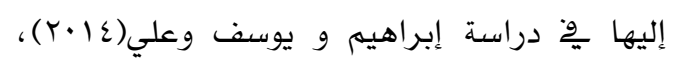

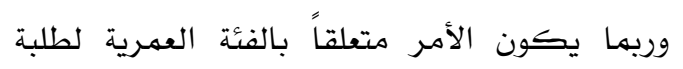

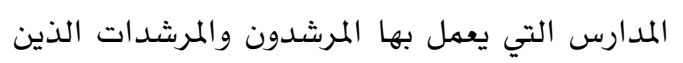

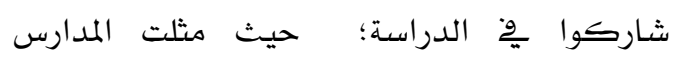

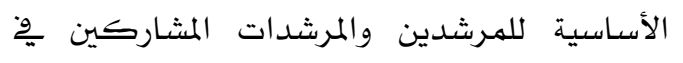
الدراسة الحالية (من الصف الأول الأسـاسي إلى لى الصف العاشر الأساسي - وفقاً لنظام التربية

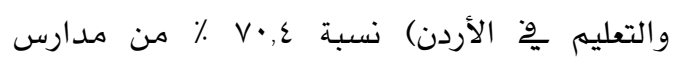

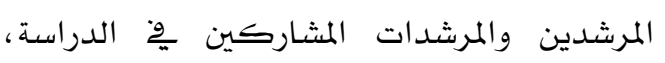

الدراسة الحالية مع دراسـة دوتي (Dottie, 2017)

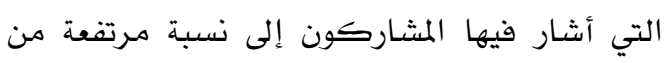

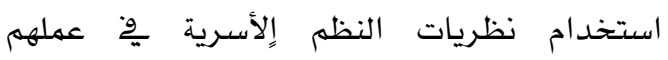

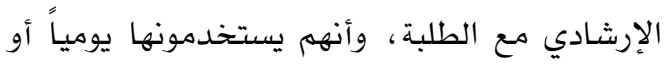

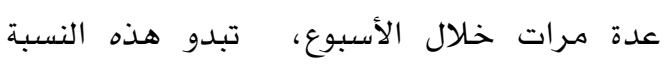

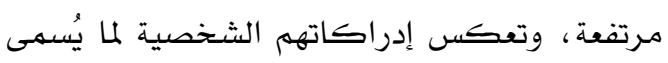
بتدخلات الإرشاد الأسري يّْ سياق المدرسة. يمكن تفسير هذه النتيجة يخ ضوء الخطط الدراسية التي يتلقاهـا المرشدون المدرسيون ِّْ جامعاتهم، والتي تتضمن بالضرورة مساقاتً ِِّْ الإرشاد الأسـري، إضافة إلى التدريب الذي يتلقونه بعد الالتحاق لاق بالخدمة، وهنا يهكن الإشـارة إلى الاهتمام الذي لي لئي أولته وزارة التربية والتعليم پِ المملكة الأردنية

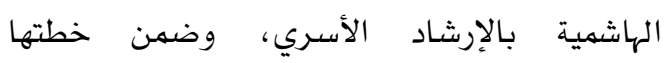
التسيقية والتشاركية مع المجلس الوطني لشؤون

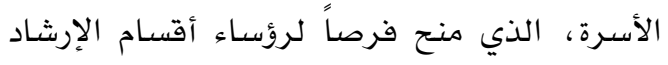

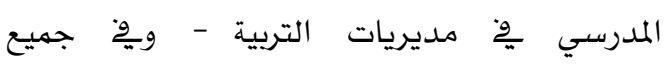
المحافظات والأقاليهم - بالتدرب على دليل الإرشاد الأسـري الذي نشره المجلس الوطني لشؤون الأسـرة،

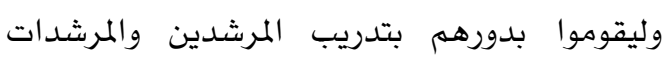

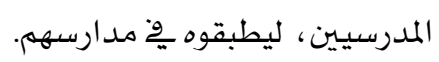

السؤال الثاني: بالنسبة إلى نتائج السؤال الثاني الذي ينص على: " ها التوجهات النظرية التي يتبناها المرشدون المدرسيون الذين يستخدمون تدخلات

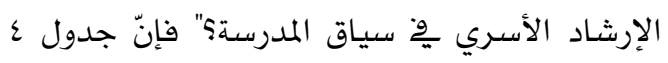

$$
\text { يوضتح ما تم التوصل إليه. }
$$

\section{جدول ؛}

التوجهات النظرية التي يتبناها المرشدون المدرسيون

\begin{tabular}{|c|c|c|c|}
\hline النسبة المئوية & التكرار & التوجه النظري & التزتيب \\
\hline$\%$ \%,० & $\varepsilon$ & الأدرلزاد الأسري & 0 \\
\hline$\% \vee, q$ & v & الانتقائي & $\varepsilon$ \\
\hline$\% 00,7$ & $\varepsilon$. & السلوكي & 1 \\
\hline$\% \backslash 0, r$ & 11 & الإنساني & r \\
\hline$\%$ \%, & r & النظم الأسرية & 7 \\
\hline$\% 11,1$ & $\wedge$ & المعرفي & $r$ \\
\hline$\% 1 \ldots$ & VY & المجموع & \\
\hline
\end{tabular}

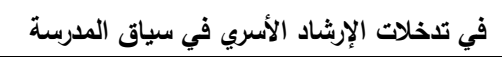


المرشدين المدرسيين لا يتلقون مساقات تتعلق بالإرشاد الأسـري، والنظم الأسـرية خلال دراسـاتهم لمرين الجامعية ، إضـافة إلى أن التدرب على النظم الأسـرية لا يظهر بِّ محاولات تحليل محتوى التدريب الذي يتلقونه، وهو تدريب يتبنى المنظور الفردي (Individual Perspective) (Systems Perspective) دوتي (Dottie, 2017) أن (وب\%) فقط من أفراد

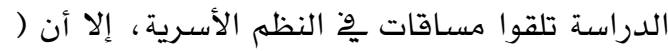
11\%7\% منهم لديهم الحماس والدافعية لتلقي مثل هذه المسـاقات إن أتيحت لهه الفرصة لذلك. السؤال الثالث: للإجابة على السؤال الثالث المتضهن "ما معتقدات المرشدين المدرسيين حول المالهئ

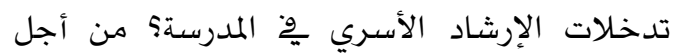
الإجابة عن هذا السؤال تم الاعتهاد على المعيار التالي يخ تحديد مستوى المعتقدات: قوية ومتوسطة وضعيفة وهذا المعيار هو:

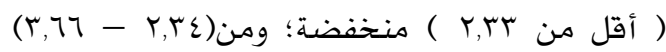
متوسطة؛و وr,TV فأكثر قوية . ولتوضيح مبررات ذلك يهكن الإشارة إلى أن مقياس

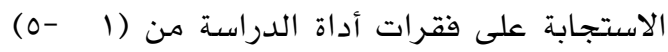
ولأغراض تقسيم مستويات المعتقدات إلى ثلاثة مستويات فقد تم اعتماد المعادلة التالية للحصول على المسافة الفاصلة بين كل مستوى والمستوى الذي يليه وهي:(0 - 1)=اr, 1, وهكذا فإن النقطة التي تلي النقطة رقم (1) هي: 1 + rr,1 = س وقد تم اعتماد هذه القيمة كنقطة قطع بحيث تعتبر متوسط الدرجات التي تقل عن هذه النقطة بأنها تقع

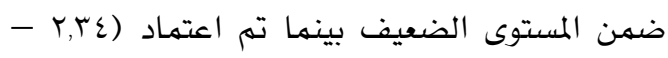

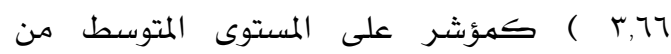
الاعتقاد، والمتوسطات التي زادت على (Y.TV) كمؤشر على المستوى القوي. ثم تم حساب المتوسطات الحسابية والانحرافات المعيارية كها هو إن مبين يٌْ جدول 0 لمعتقدات المرشدين المدرسيين حول الإرشـاد الأسـري ِِّ سياق المدرسـة.
مقارنة بالمدارس الثانوية، التي شكلت فقط ما نسبته ب9,7\% من مدارس المرشدين والمرشدات المشاركين يخ الدراسـة.

من ناحية أخرى، تختلف هذه النتيجة هع ما توصلت

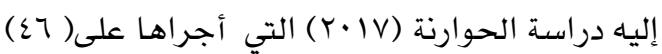

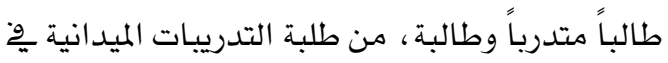

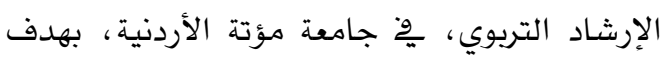
التعرف على الصعوبات التي يواجهون خلال فترة التدريب الميداني يُّ المدارس، وقد أشارت نتائج الدراسة إلى أنهم يواجهون صعوبات متوسطة ِون متابعة المثاكل السلوكية لدى الطلبة، وتتفيذ براهج تعديل السلوك، التي تستتد إلى مبادئ الإرشاد السلوكي. وربها تعود مثل هذه الفروقات

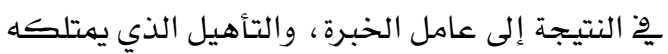
المرشدون المدرسدون الملتحقون بالخدمة مقارنة بطلبة التدريب الميداني الذين طُبقت عليهم دراسـة الحوارنة .$(Y \cdot I V)$ وفيما يتعلق بقلة استخدام نظريات النظم الأسرية يخ أوسـاط المرشدين المدرسيين (family systems) الذين تتم مطالبتهم بالتعاون والعمل مع أسر الطلبة بما يخدم نموهم، وتحديد أدوار وواجبات تؤكد على إشراك الأسـرة ِّخ العمل الإرشادي - وهي نتيجة تتسق هـ نتيجة دراسة بيروس وجودانف (Perusse \& Goodenough, 2005) إلى أن المرشدين صنفوا أن الحاجة للتدرب على مجال (الإرشاد الزواجي والأسري) بشكل عام ضهن المجالات الأقل أهمية، وهذا يعكس

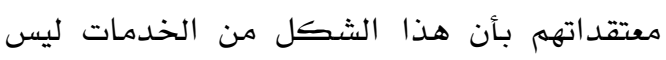
ضهن مهامهم كهرشدين مدرسيين، وبهذا أيضاً

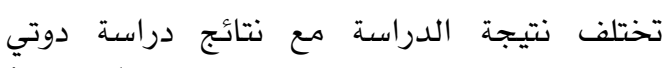
(Dottie, 2017)

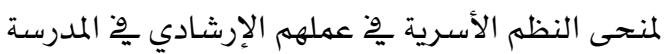
على أسـاس يومي. يهكن توضيح هذه النتيجة من خلال الاستعانة بتصريح بايلو (Paylo, 2011) الذي أشار إلى أنّ أكثر من نصف المرشدين، حوالي (01,9) من 


\section{جدول}

المتوسطات الحسابية والانحرافات المعيارية لمعتقات المرشدين المدرسيين مرتبة تنازلياً حسب المتوسطات الحسابية

\begin{tabular}{|c|c|c|c|c|}
\hline الاتحراف المعياري & المتوسط الحسابي & 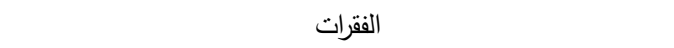 & 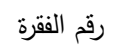 & 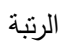 \\
\hline., 070 & $\varepsilon$, or & إن استخدام الإرشاد الأسري في خدمة الطلبة مفيد لهم & 1 & 1 \\
\hline$\cdot, 0 \leqslant 1$ & $\varepsilon, \S \wedge$ & نموهم المختلفة الإششاد الأسري على تفهم الأسرة لحاجات أبنائها في مراحل & 7 & r \\
\hline$\cdot, 0 \wedge r$ & $\varepsilon, \Sigma\rceil$ & والأيناء الإرشـاد الأسـري مـن فـرص التواصـل الايجـابي بـين الآبـاء & $\wedge$ & r \\
\hline$\cdot, 011$ & $\varepsilon, \varepsilon \varepsilon$ & 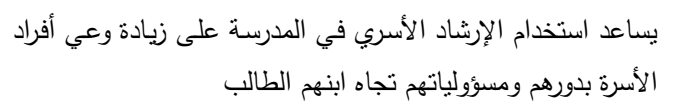 & $\checkmark$ & $\varepsilon$ \\
\hline$\cdot, 0 \wedge \mathrm{V}$ & $\varepsilon, r \uparrow$ & 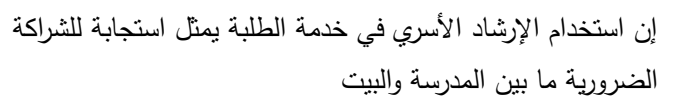 & 1. & $\circ$ \\
\hline$\cdot, 0 \leq 0$ & $\varepsilon$, ro $_{0}$ & خلال الإرشاد الأسري مشكلات الطلبة في الوقت الحاضر يستدعي التدخل من & r & 1 \\
\hline$\cdot, 0 \leq 0$ & $\varepsilon$, TO $_{0}$ & 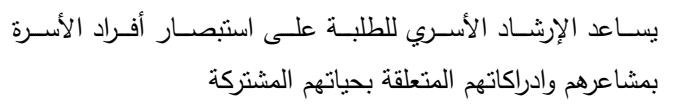 & ir & v \\
\hline$\cdot, 717$ & 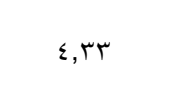 & لبزيـــــالإرشـاد الأسـري للطلبـة مـن إمكانيـة فهم وتقبـل أفراد الأسـرة & $1 \leqslant$ & $\checkmark$ \\
\hline 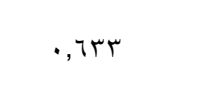 & $\varepsilon, r \mu$ & 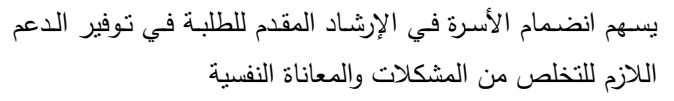 & 10 & 9 \\
\hline$\cdot, 1 \leq \wedge$ & $\varepsilon, r$ & نظرهم الإرشاد الأسري فرصا اكبر للطلبة وذويهم للتعبير عن وجهات & ir & 9 \\
\hline$\cdot, 0 \wedge \varepsilon$ & $\varepsilon, r$. & أعتقد أن استخدام الإرشاد الأسري يسهل عمل المرشد المدرسي مع & 9 & 1. \\
\hline$\cdot, V \leqslant r$ & $\varepsilon, Y T$ & 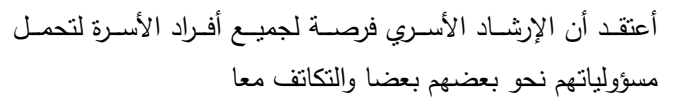 & 17 & 11 \\
\hline$\cdot, \vee \circ \leqslant$ & $\varepsilon, Y_{0}$ & وأرى أن الإرشـاد الأسـري يسلط الضوراء على دور الأسرة في نشأة & 11 & Ir \\
\hline 9 & $\varepsilon, r$, & أعتقد انه يمكن للإرشاد الأسري للطلبة أن بسهم في الحد من تفاقم & $\varepsilon$ & IT \\
\hline$\cdot, V \circ V$ & $\varepsilon, Y r$ & أعتقد أن استخدام المرشــ المدرسي لخيـار الإرشـاد الأسـري في & 0 & IT \\
\hline$\cdot, \vee \backslash \wedge$ & $\varepsilon, 1 T$ & 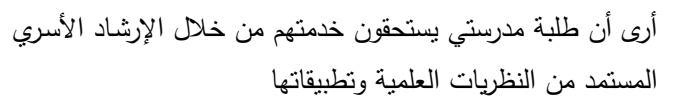 & $r$ & 10 \\
\hline$\cdot, r \wedge \varepsilon$ & $\varepsilon, \Gamma r$ & سباق المدرسة المرشدين المدرسيين حول تدخلات الإرشاد الأسري في & & \\
\hline
\end{tabular}

عـ,ع ، وهـي تتعلق باعتقــادات المرشـدين المدرسـيـين بـأن الإرشـاد الأســري يسـاعد علـى تفهـم الأســرة لحاجـات أبنائهـا بِّة مـراحل نهـوهم المختلفـة، ويزيـد من فرص التواصل الايجابي بين الآباء والأبناء، على قيام أفراد الأسـرة بـدورهم ومسؤولياتهم تجـاه ابنهـم الطالب. تتسـجم هـــه النتيجــة مـع مـا توصـلت إليـهـ

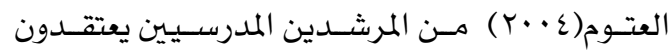

يبيين جـدول ه أن المتوسـطات الحسـابية قد تراوحت

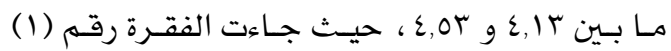
والـتي تنص على "إن اسـتخدام الإرشــاد الأسـري ِِّ

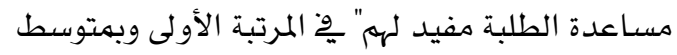

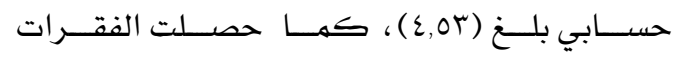

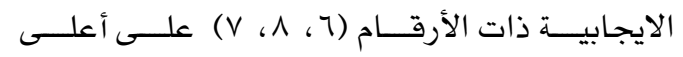

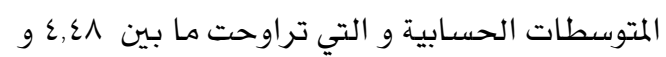


وقد تعني هذه النتيجة - من جهة أخرى - أن أن المرن

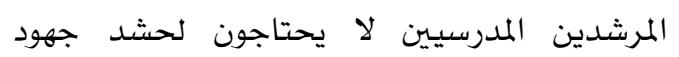

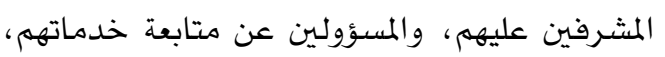
لإقناعهم بضرورة وأهمية وقيمة استخدام تدخلات الإرشاد الأسري پِّ سياق المدرسة، مقابل الاهتمام

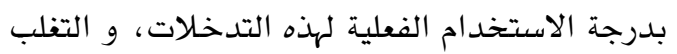

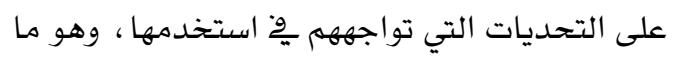
يحاول السؤالان الرابع والخامس الإجابة عليها. السؤال الرابع: للإجابة عن السؤال الرابع والذي

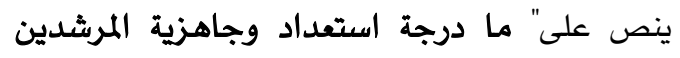

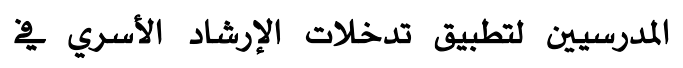
سياق المدرسة؟ تم استخراج المتوسطات الحسابية

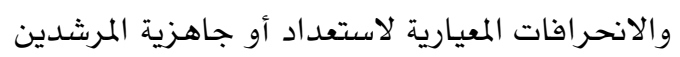
التربويين لتطبيق لتحديات تطبيق تدخلات الإرشاد الأسري بِّ سياق المدرسة ، وجدول 7 يوضح ذلك. تلكئ. يبين جدول 1 أنّ المتوسطات الحسابية قد تراوحت

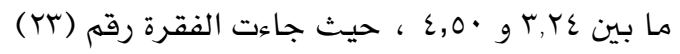
والتي تتص على"أتحمس لتطبيق الإرشاد الأسري

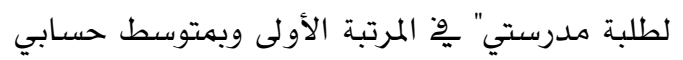

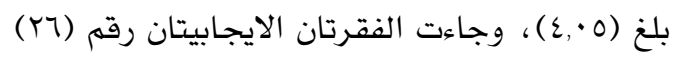

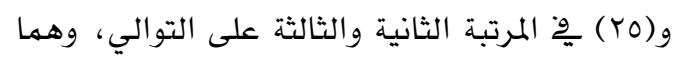

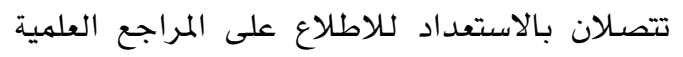

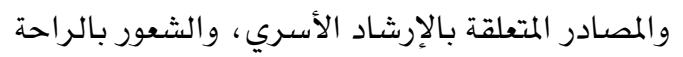

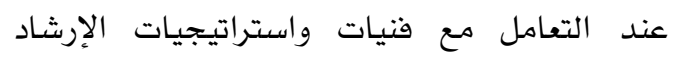

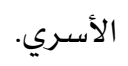

وجاءت الفقرة رقم (19) ونصها "لدى الوقت الكايو

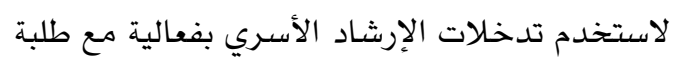

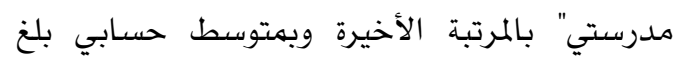

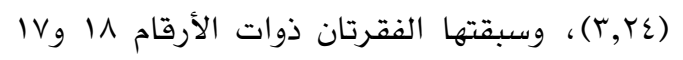

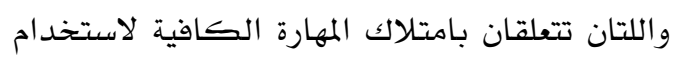

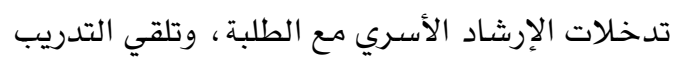

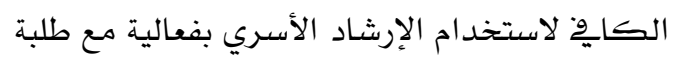

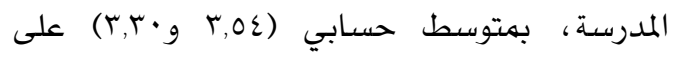
التوالي؛ إنّ هذه النتائج تعني درجة استعداد وجاهزية

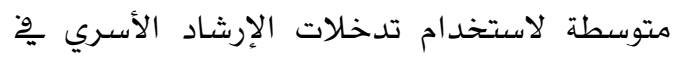
سياق المدرسة بالنسبة لتوافر المهارات الكافية لإنة الاستري
بوجـود حاجـة عاليـة لاسـتخد ام الإرشـاد الأسـري ِوِ

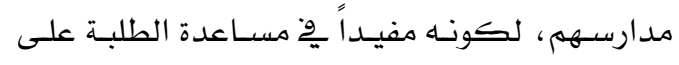

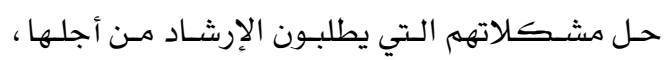

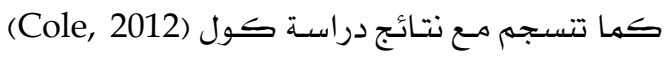

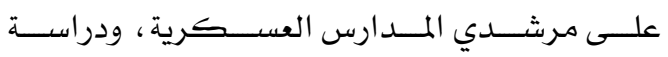

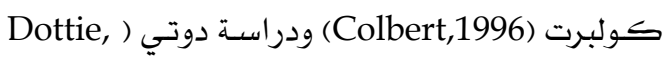

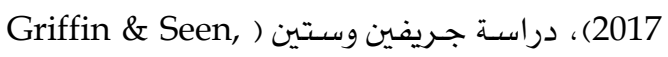

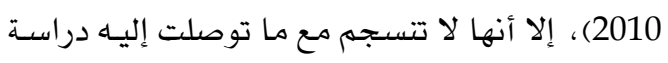

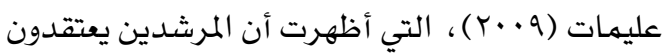

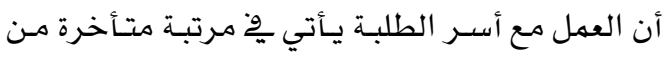
عملهم الإرشادي وِّ المدرسة.

وجاءت الفقرة رقم (r) ونصها "أرى أن طلبة

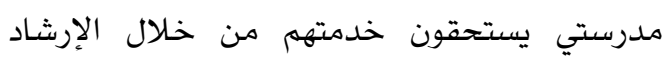

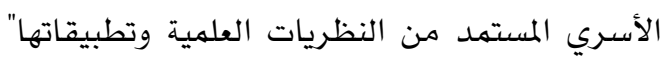

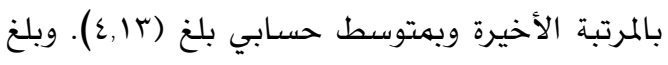

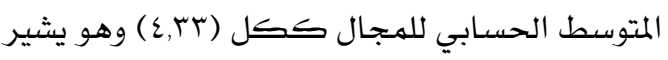
إلى أن المرشدين المدرسيين لديهم معتقدات ايجابية

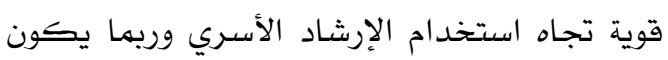

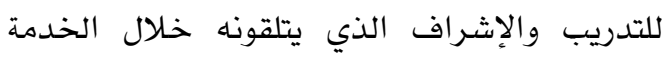

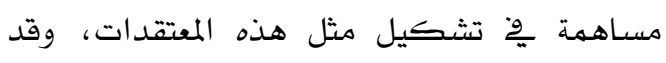

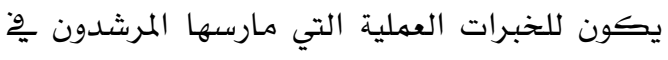

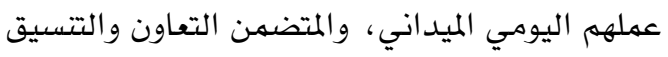

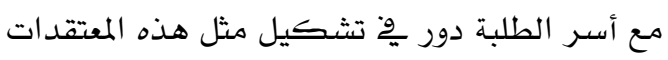

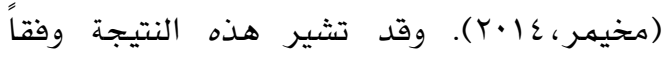

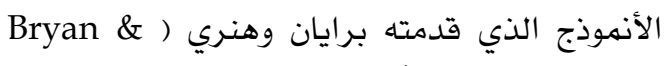
المسمهى(نهوذج عملية الشراكة) (Henery, 2012

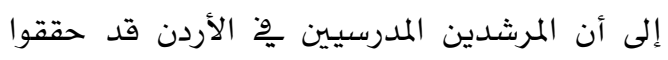

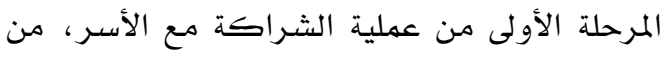

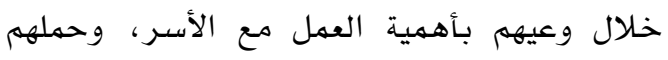
لمعتقدات قوية تجاه تطبيق تدخلات الإرشاد الأسري، وأن عليهم التقدم نحو خطوات أكثر تلفراه

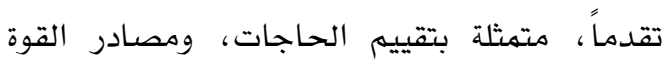

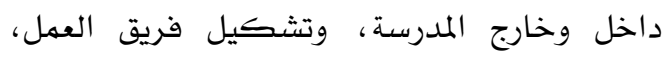
وتطوير رؤية مشتركة، وخطط تتفيذية، والتقييم

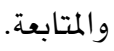


لممارسة الإرشاد الأسـري، من خلال اكتسـاب

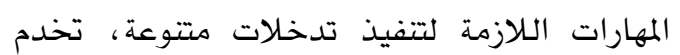
الطلبة وأسرهم، فالمهارات الإرشادية التي يمتلكها المرشد، ، وشعوره بالكفاية والاقتدار تهاه استخدامها يعد من أقوى الدوافع التي تحرك المرشد المدرسي لتقديم خدمات إرشادية من نوع محدد

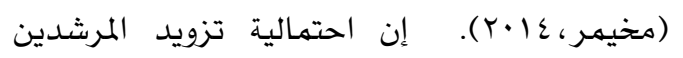

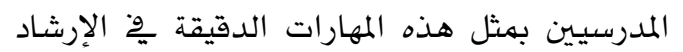
الأسري ِِّ سياق المدرسة قد يتطلب المزيد من الإيهان باه من قِبل مشريخِ الإرشاد النفسي المسؤولين

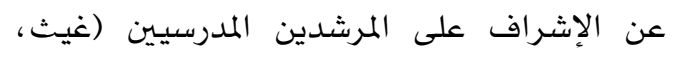

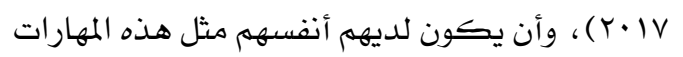

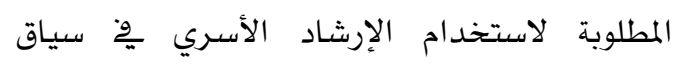
المدرسة ، أو أن يقوموا بالاستعانة بالخبراء والمدربين المحترفين لتقديم مهارات وكفايات الإرشاد الأسـري

للمرشدين.

لاستخدام الإرشاد الأسري ِّْ سياق المدرسة ، ودرجة

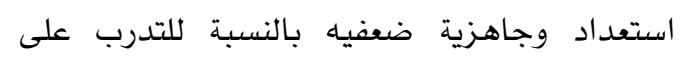
الإرشاد الأسـري ِِّ سياق المدرسـة. من جهة أخرى، بلغ المتوسط الحسابي للهجال ككل (Y, (Y)، مها يشير إلى أن درجة استعداد أو جاهزية أو المرشدين

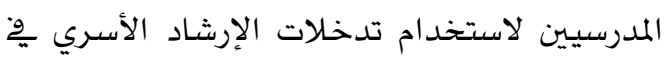

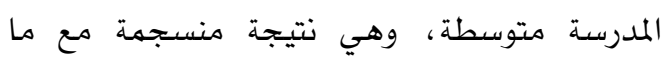
توصلت إليه دراسـة دوتي (Dottie, 2017)، التي أشارت إلى أن استعداد المرشدين المدرسيين

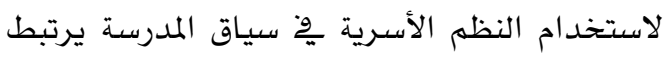

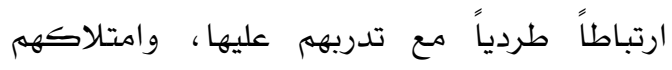
للمعرفة والمهارات المتصلة بها.

يمكن القول أن المرشدين المدرسيين بحاجة إلى المزيد من التدرب على نظريات وفنيات الإرشاد الأسري ِّ سياق المدرسة، وأن هذا التدريب

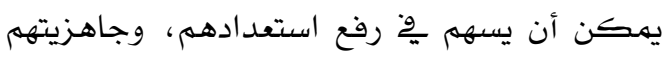
جدول 1

المتوسطات الحسابية والانحرافات المعيارية لاستعداد وجاهزية المرشدين التريويين لتطبيق تدخلات الإرشاد الأسري في سياق المدرسة مرتبة تنازلياً حسب المتوسطات الحسابية

\begin{tabular}{|c|c|c|c|c|}
\hline الانحراف المعياري & المتوسط الحسابي & 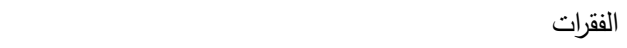 & 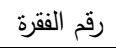 & 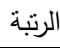 \\
\hline,$\vee \wedge$. & $\varepsilon, 0$. & أتحمس لتطبيق الإرشاد الأسري مع طلبة مدرستي & rt & 1 \\
\hline, $9 \leqslant \wedge$ & ґ,^q & 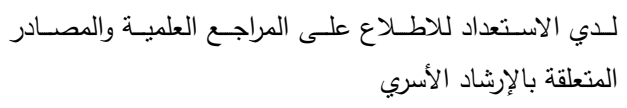 & r & r \\
\hline , 101 & ґ,^т & الأســعر بالراحـة عند التعامل مـع فنيـات واستراتيجيات الإرشـاد & ro & r \\
\hline $1, .07$ & r, & 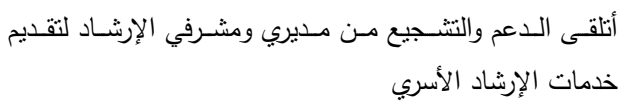 & $r \varepsilon$ & $\varepsilon$ \\
\hline 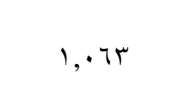 & $r, \tau$. & متل هذا الأسلوب في الإرشاد أستراتيجيات الإرشـاد الأسري عند استخدام & r. & 0 \\
\hline $1, \cdot \varepsilon \leqslant$ & r,०ᄉ & أشتعر أنني كفؤ في تطبيق أسلوب الإرشاد الأسري & r) & 7 \\
\hline $1, \cdot r \varepsilon$ & r,ov & أعتقد أنّ الإرشاد الأسري للطلبة في مدرستي قابل التنفيذ من & rt & $\checkmark$ \\
\hline $1, .99$ & $r, 0 \leqslant$ & طلبة مدرستي أمهارة الكافية لاستخدام تدخلات الإرشاد الأسري مع & 11 & $\wedge$ \\
\hline $1, r \cdot r$ & $r, r$. & طلقيت مدرستي التذريب الكافي لاستخدام الإرشاد الأسري بفعالية مع & iv & 9 \\
\hline 1,171 & $r, r \varepsilon$ & للاى الوقت الكافي لاستخدم تدخلات الإرشاد الأسري بفعالية مع & 19 & 1. \\
\hline,$V \cdot r$ & r, 10 & 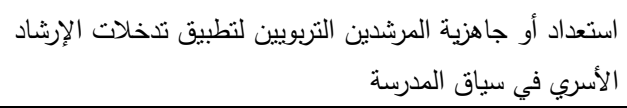 & & \\
\hline
\end{tabular}


الأسـري وِّ المدرســة ، وهـو مـا لا يفضــله المرشــدون

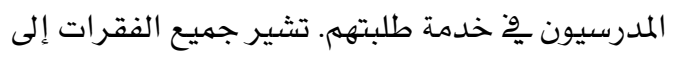

تحديات بدرجة مرتقعة.

مـن جهـة أخــرى، جـاءت الفقـرة رقـم (YV) ونصـها

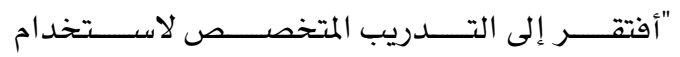

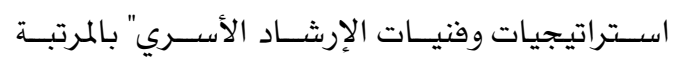

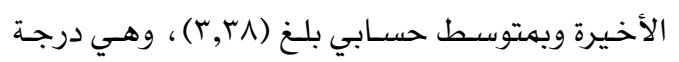

السؤال الخامس: للإجابة عن السؤال الخامس

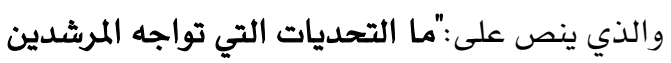

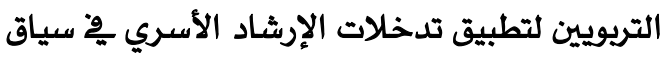

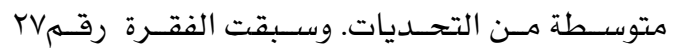
المدرسة \& تم استخراج المتوسطات الحسابية والانحرافات المعيارية لتحديات تطبيق تدخلات

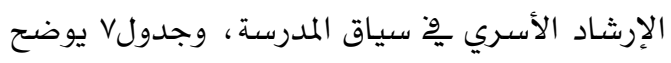
ذلك.

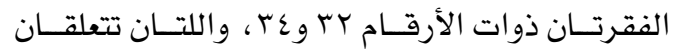

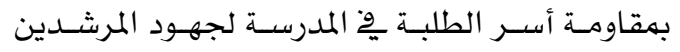

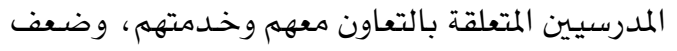

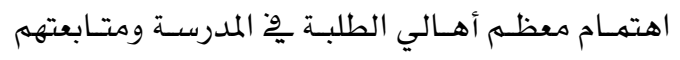

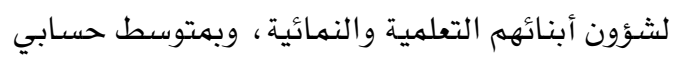

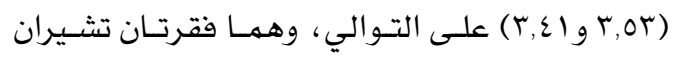

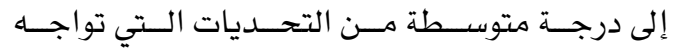

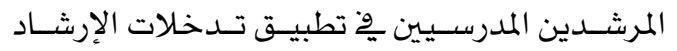
الأسري ״ِّ سياق المدرسة. وتتفق نتيجة هذا السؤال

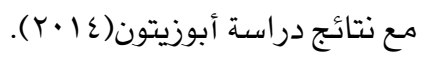
يبين جـدول V أن المتوسـطات الحسـابية قد تراوحت

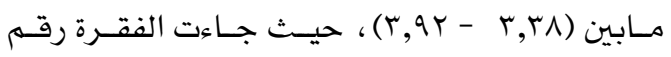

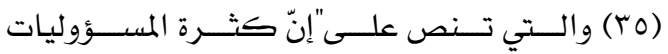

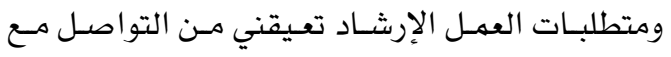

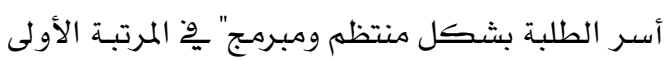

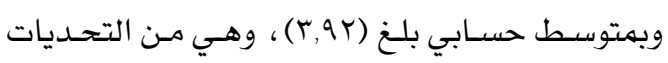

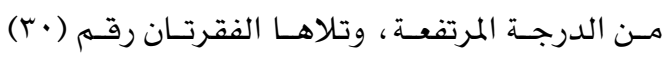

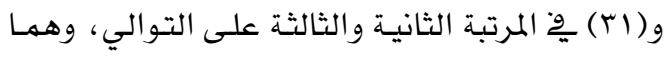

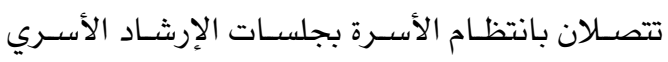

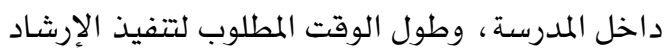

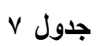

المتوسطات الحسابية والانحرافات المعيارية لتحديات تطبيق تدخلات الإرشاد الأسري في سياق المدرسة مرتبة تنازلياً حسب المتوسطات الحسابية

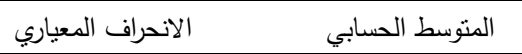
الفقرات الرنبة

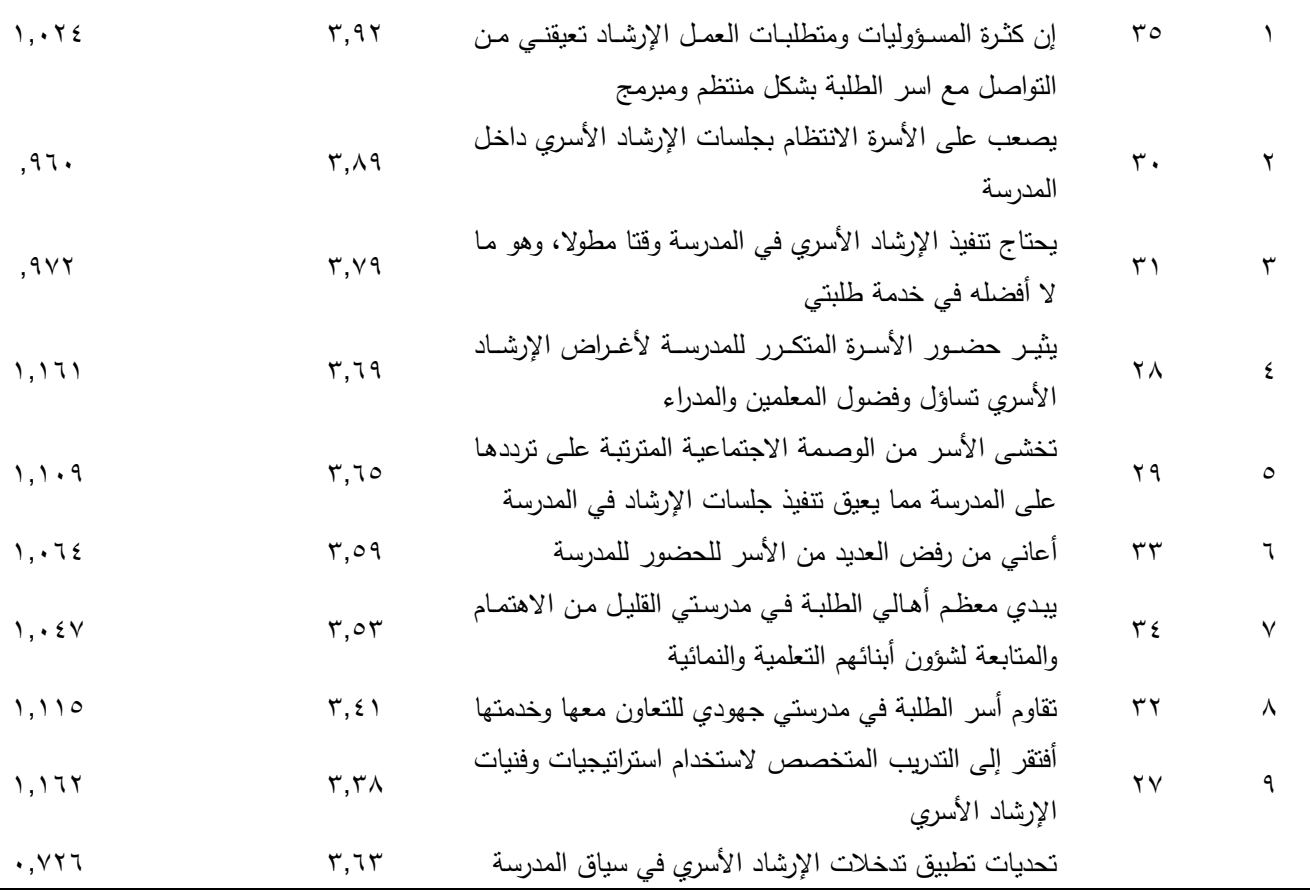




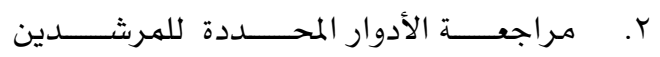

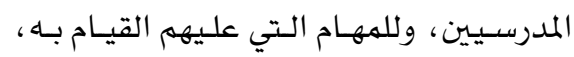

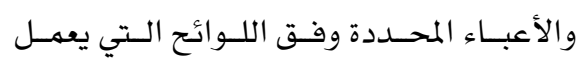

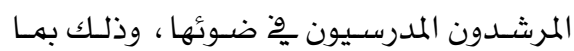

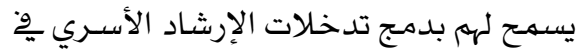
سياق المدرسـة ، والاسـقفادة مـن مزاياهـا التي لتي تعود على نهو وتحصيل الطلبة. r. انفتــاح وتـدريب المرشـــين المدرسـيـين علـى

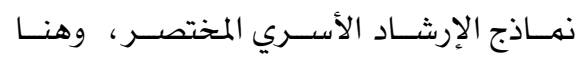
يهكن التوصية باستخدام الإرشـاد الأسـري

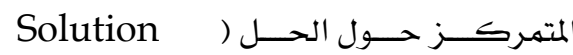
(Focused family counseling )، والتي مـن شــأنها أن تهـكـهـم مـن التفلـب علـى تحـدي ضغط الوقت وكثرة الأعبـاء والمهام الوظيفية التي بـرزت كأحسد أهـم التحـديات التي تواجههم فِّ استخدام تـدخلات الإرشـاد الأسـري بِّ سـياق المدرســة ، وبـنفس الوقت

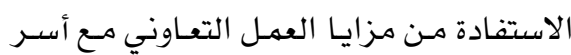
الطلبة بالاستتاد إلى نظريات وفنيات الإرشاد الأسـري. ع.أن تشتهل خطط وبراهج التدريب الميـداني

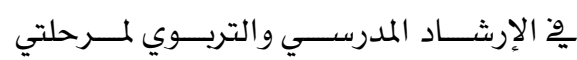

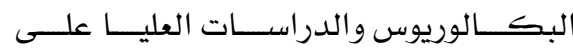
مسـاقات وتـدريبات عمليـة تتعلق باسـتخدام تدخلات الإرشـاد الأسـري ِِِّ سياق المدرسة.

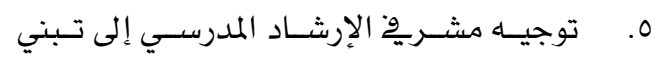

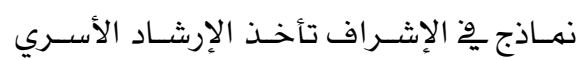
سياق المدرسة بالاعتبار

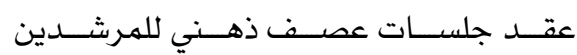
المدرسـيـين لتجـاوز تحسديات تطبيـق تـدخلات

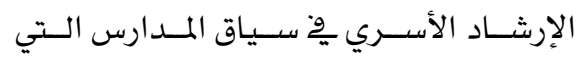
يعملون فيها.
ودراسـة دوتـي (Dottie, 2017)، ودراســة هنـري

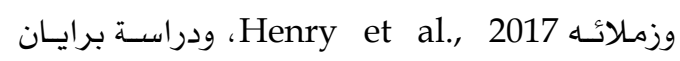
وهنري ( Bryan \& Henry, 1012 ) و ودراسة كوك ودك وزمـلائها (cook et al., 2016) الـتي أشـارت إلى معيقـات تتعلق بكثرة الأعبـاء المهنيـة ، وقلـة الوقت

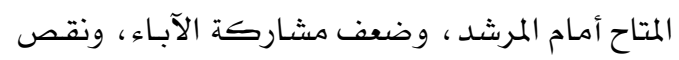
التدريب على التدخلات الأسـرية.

أهـا بالنسـبة إلى المتوسـط الحسـابي للهجـال ككل

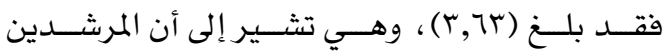
المدرسيين يواجهون تحديات تطبيق تدخلات الإرشاد الأسـري پِّ سياق المدرسـة بدرجة متوسطة. وقد تعـني

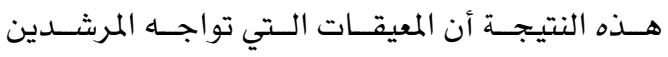
المدرسـيـين لاسـتخدام تـدخلات الإرشــاد الأســري يهكـن مواجهتهـا مـن خـلال تطـوير آليـات وخطـط تســـل مـن تجــاوز العقبـات، وتذليلـها ، خاصــة وأن المرشـدين يحملـون معتقــات ايجابيـة قويـة حـول هـذا

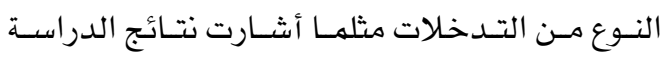

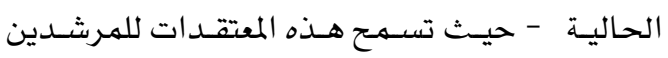
المدرسيين بالتقدم نحو تطبيقها. ويمككن للتسـيق المشـترك بـين المرشـدين المدرسيـين

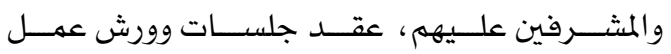
للستفكير بطــرق لتجــاوز التحـديات، وقـد يكــون

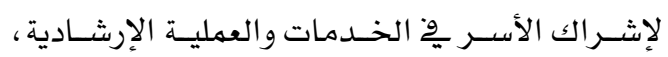

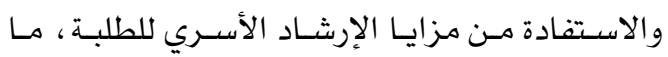
يهيئ الفرص لزيادة فعاليـة هـذه الخـدمات واسـتفادة الطلبـة ، وهـــو الهـدف المنشــود مـن خــدمات الإرشــاد

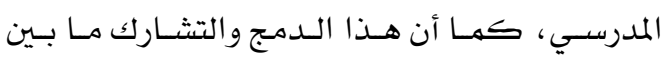

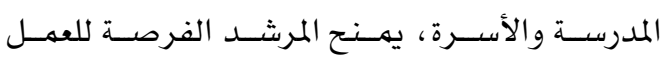
بأسلوب معاصر يتتاسب مـع طلبـة الألفيـة الثالثة ومـا

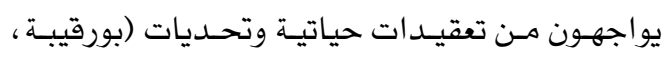
(Y... التوصيات

ا. عمـل دورات تدريبيـة متخصصسة للمرشـدين التربـويين تتعلق باسـتخدام نظريـات وفنيـات

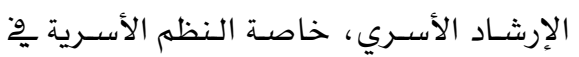
سياق المدرسـة. 
السودان لعلوم والتكنولوجيا، 10 (TI)، .V. - Or

الحجيري، رزان (rا+ץ). درجة ممارسة المرشد التريوي للإرشاد الأسري من وجهة نظر مديري المدارس والطلبة. رسالة ماجستير غير منشورة. جامعة عهّان العربية. الأردن. الحوارنة، إياد (YV). Y. الصعوبات التي تواجه طلبة الإرشاد النفسي يْ التدريب الميداني من وجهة نظرهم. مجلة مؤتة للبحوث والدراسات، سلسلة العلوم الإنسانية والاجتماعية، جامعة مؤتة - الأردن، YY (0)، 119

الرواشدة، شـذى (rا•r). مستوى ادراك معلمي غرف المصادر بِ محافظة الكرك لحاجات أسر الطلبة لخدمات الإرشـاد والتوجيه الأسـري. رسالة ماجستير غير منشورة، جامعة مؤتة اية

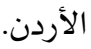

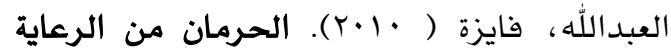
الوالدية وعلاقته ببعض المتغيرات: دراسة ميدانية على طلاب الحلقة الثانية من التعليم الأساسي ِوْ مدينة دمشق. رسالة ماجستير غير منشورة، جامعة دمشق - سوريا. العتوم، نادية (ع ·). الحاجة للإرشاد الأسري من وجهة نظر المرشدين التربويين ِِّ محافظات شمال الأردن. رسـالة ماجستير غير منشورة، ومترة جامعة اليرهوك، اريد - الأردن.

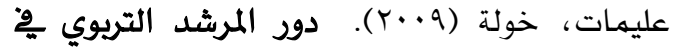
التعامل مع ظاهرة التسرب المدرسي خلال مرحلة التعليم الأساسي مِّ محافظة جرش. رسالة ماجستير غير منشورة، الجامعة الأردنية - الأردن. - ماجن.

غيث، سعاد؛ وطقش، حنان (· • (Y). فعالية برنامج إرشـادي يستـد إلى النظرية العقلانية الاتفعالية

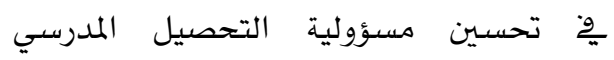
والكفاءة المدركة لدى طالبات الصف

\section{المراجع}

\section{References}

$$
\begin{aligned}
& \text { أبو زيتون، جمال (عا •Y). مدى ممارسـة المرشدين } \\
& \text { التربويين للأدوار والمهمات الوظيفية المطلوبة } \\
& \text { منهم للتعامل مع الطلبة ذوي الحاجات. مجلة } \\
& \text { العلوم التربوية والنفسية - جامعة البحرين، } \\
& . r v 1-r \varepsilon r_{0}(\varepsilon) 10
\end{aligned}
$$

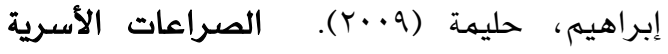

$$
\begin{aligned}
& \text { وعلاقتها بالاكسئاب والقلق لدى المراهق } \\
& \text { الكويتي. رسالة ماجستير غير منشورة ، جامعة } \\
& \text { الكويت - الكويت. }
\end{aligned}
$$

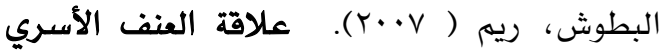
والتوتر النفسي لدى الزوجات المعنفات والأبناء المساء إليهم مع بعض المتفيرات الديموغرافية. رسالة ماجستير غير منشورة، جامعة مؤتة،

$$
\text { الكرك - الأردن. - الك }
$$

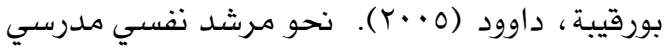

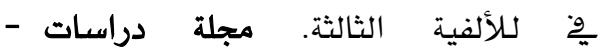
الجزائر، r.

بوغازي، كريمة؛ وعرييي، سعيدة (7 (Y). الإرشاد الأسري لآباء الأطفال ذوي صعوبات التعلم. مجلة جيل العلوم الإنسانية والاجتماعية،

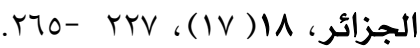

حامد، صباح ؛ وطالب، ابراهيم (عا+ץ). دور المرشد الطلابي پِّ التعامل مع مشكلات العنف الأسرى لطلاب المرحلة الثانوية بالرياض. مجلة العلوم الإنسانية - جامعة 
Barrow, G. (2011). The role of professional school counselors in working with students in gangs: A grounded theory study. A dissertation By: Raleigh, North Carolina University. Retrieved from ProQuest Database, UMI Number: 3497190.

Bryan, J., \& Henry, L. (2008). Strengthsbased partnerships: A school-familycommunity partnership approach to empowering students. Professional School Counseling, 12, 149-156.

Bryan, J., \& Henry, L. (2012). A model for building school-family-community partnerships: Principle sand process. Journal of Counseling and Development, 90, 408-420. doi:10.1002/j.1556-6676.2012.00052.x

Campbell, J. (2009).Attitudes and beliefs of counselor educators toward gatekeeping. Retrieved from ProQuest Database, UMI Number 3354261.

Carter, M., \& Evans, W. (2008).Implementing school-based family counseling: strategies, activities, and process considerations. International Journal for School-Based Family Counseling, 1, 5, 1-13, .

Carter, S. (2016). Multicultural counseling programs. Research Starters Education, 1, 1-14. Retrieved from: Research Starters - Education Database.

Crespi, T., \& Hughes, T. (2004). Schoolbased mental health services for adolescents: School psychology in contemporary society. Journal of Applied School Psychology, 20, 1, 67-78.

Cripps, K., \& Zyromski, B. (2009). Adolescents' psychological well-being and perceived parental involvement: Implications for parental involvement in middle schools .Research in Middle Level Education Online, 33, 4, 1-13.

Cook, A., Brayn, J., \& Belford, P. (2016). Implementation of a school-familycommunity partnership model to promote Latina youth development: reflections on the process and lessons. International Journal of Research on Service-Learning and Community Engagement, 4, 1, 1-18. Retrieved from: https://www.researchgate.net/public ation/311994019.

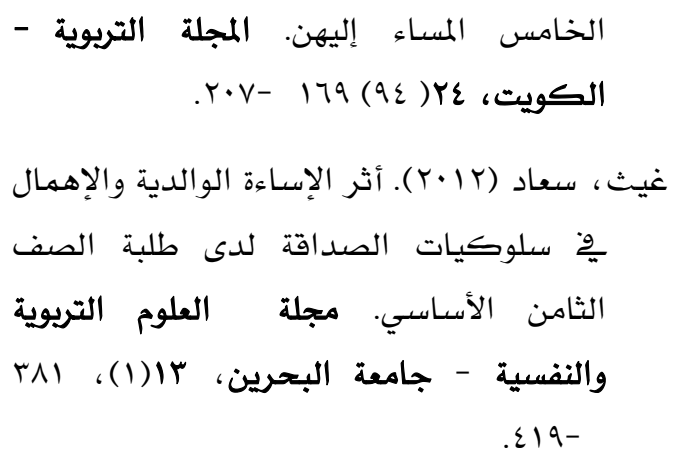


Cole, R.(20120. Professional School Counselors' role in partnering with military families during the stages of deployment. Journal of School Counseling, 10, 7. Retrieved from: https://eric.ed.gov/?id=EJ978863.

Colbert, R.(1096). The counselor's role in advancing school and family partnership. School Counselor, 44, 2,100105.

Diorio, G. (2016). Parent volunteers in schools. Research Starters Education.3,1, 1-12. Retrieved from: Research Starters - Education Database.

Dottie, M. (2017). School counselors' perceptions of family systems perspectives. The Family Journal, 25, 3.Doi: 10.1177/1066480717711109.

Farrell, A and Collier, M. (2010). School personnel's perceptions of familyschool communication: A qualitative study. Improving Schools, 13, 1, 120.DOI: $10.1177 / 1365480209352547$.

Gerrard, B. (2008). School-based family counseling, overview, trends, and recommendations for future research. International Journal for School-Based Family Counseling, 1, 1. Retrieved from: schoolbasedfamilycounseling.com/.../I JSBFC.

Griffin, D., \& Steen, S. (2010). Schoolfamily-community partnerships: Applying Epstein's theory of the six types of involvement to school counselor practice. Professional School Counseling, 13, 218-226.

Henderson, A., Sager, T. \& Horne, A. (2003). Mothers and sons: a look at the relationship between child behavior problems, marital satisfaction, maternal depression, and family cohesion. Family Journal: Counseling and Therapy for Couples and Families, 11, 3341.

Henry, L., Bryan, J., and. Zalaquett, .P. (2017). The Effects of a counselor faithbased, school-family-community partnership on Student achievement in a high-poverty urban elementary school. Journal of multicultural counseling and development, 45,162- 128. DOI: 10.1002/jmcd.12072.
Holcomb-McCoy, C. (2004). Using the family autobiography in school counselor preparation: an introduction to a systemic perspective. .Family Journal: Counseling and Therapy for Couples and Families, 12, 1, 21-25.

Kim, J. . Mayes, R.. Hines E. \& Bryan, J. (2017): The parent-high school Counselor relationship and dtudents' postsecondary enrollment. Journal of Counselor Leadership and Advocacy, 1, 3. Published online: doi:10.1080/2326716X.2017.1322929

Lagana, M. (2004). Protective factors for inner-city adolescents at risk of school dropout: family factors and social support. Children $\mathcal{E}$ Schools, 26,4, 211220.

Laible, D. (2011). Does it Matter if preschool children and mothers discuss positive vs. negative events during reminiscing? links with motherreported attachments, family emotional climate, and socioemotional development. Social Development, 20, 2.

Lewis-Antoine, N. (2012).Teachers and parents' perceptions of Barriers to Parental Involvement in an Alternative High School. A dissertation By: Walden University. Retrieved from ProQuest Database, UMI Number 3498258.

Ludwig, S. (2016). School health services. Research starters education. 3, 1, 1-12. Retrieved from: Research Starters Education Database.

Mason, E. (2010).Leadership Practices of school counselors and counseling program implementation. NASSP Bulletin, 94, 4. DOI: 10.1177/0192636510395012.

Martin, D.(2017) School Counselors' Perceptions of Family Systems Perspectives. The Family Journal, 25,3. DOI:10.1177/1066480717711109.

Mazgon, J., \& Mrvar, P. (2017)The role of the school counselor in schoolcommunity collaboration: The case of Slovenia. International Journal of Cognitive Research in Science, Engineering and Education, 5,1,19-29. 
Messin, K., Kolbert., Hyatt-Burkhart, D., \& Crothers, L. (2015). The role of mental health counselors in promoting schoolfamily collaboration within the tiered school-wide positive behavioral intervention an support (SWPBIS) mode. The Family Journal: Counseling and Therapy for Couples and Families 2, 3, 277-285. DOI: 10.1177/1066480715574471.

Mellin, E., Belknap, E., Brodie, L., \& Sholes, K. (2015). Opening school doors to communities and families: A social capital perspective for multiparty collaboration. Journal for Social Action I Counseling and Psychology, 7, 1, 1-18. Retrieved from http://jsacp.tumblr.com.

Mullis, F., \& Edwards, D. (2001).Consulting with parents: Applying family systems concepts and techniques. Professional School Counseling, 5, 2, 116 - 123.

Paylo, M. (2011). Preparing schoolcounseling students to aid families: Integrating a family systems perspective. The Family Journal: Counseling and Therapy for Couples and Families, 19, 2, 140-146.

Perusse, R., \& Goodnough, G. (2005).Elementary and secondary school counselor's perceptions of graduate preparation programs: A national study. Counselor Education and Supervision, 45, 109-118.

Sheridan , S., Kratochwill, Th., Burt, J., \& Clarke, B. (2009). Conjoint behavioral consultation: Promoting family-school connections and interventions. Springer Publication.

Snyder, M. (2010). Teachers' Perceptions of students needs toward school-based family counseling. A dissertation By: Capella University. Retrieved from ProQuest Database, UMI Number 3390330.

Stone, C., \& Dahir, C. (2015). The transformed school counselor. Third edition. Cengage Learning, Boston, USA.

Sweeney, Th. (2009). Adlerian counseling and psychotherapy: A practitioner's approach, fifth edition. Rutledge Publication.
Tan, T., \& Goldberg, W. (2009).Parental school involvement in relation to children's grades and adaptation to school. .Journal of Applied Developmental Psychology, 30, 3, 442-453.

Terry, L. (2002). Family counseling in the schools: a graduate course. Family Journal: Counseling and Therapy for Couples and Families, 10, 4, 419-428.

Van Velsor, P. \& Cox, D. (2000). Use of collaborative drawing technique in school counseling practicum: an illustration of family systems. Counselor Education and Supervision, 40, 2, 141152. 